Review

\title{
Nanoparticles of Quaternary Ammonium Polyethylenimine Derivatives for Application in Dental Materials
}

\author{
Marta Chrószcz * (D) and Izabela Barszczewska-Rybarek (D) \\ Department of Physical Chemistry and Technology of Polymers, Silesian University of Technology, \\ 44-100 Gliwice, Poland; izabela.barszczewska-rybarek@polsl.pl \\ * Correspondence: Marta.Chroszcz@polsl.pl; Tel.: +48-(32)-2371793
}

Received: 9 September 2020; Accepted: 28 October 2020; Published: 30 October 2020

check for updates

\begin{abstract}
Various quaternary ammonium polyethylenimine (QA-PEI) derivatives have been synthesized in order to obtain nanoparticles. Due to their antibacterial activity and non-toxicity towards mammalian cells, the QA-PEI nanoparticles have been tested extensively regarding potential applications as biocidal additives in various dental composite materials. Their impact has been examined mostly for dimethacrylate-based restorative materials; however, dental cements, root canal pastes, and orthodontic adhesives have also been tested. Results of those studies showed that the addition of small quantities of QA-PEI nanoparticles, from 0.5 to $2 \mathrm{wt}$ \%, led to efficient and long-lasting antibacterial effects. However, it was also discovered that the intensity of the biocidal activity strongly depended on several chemical factors, including the degree of crosslinking, length of alkyl telomeric chains, degree of $\mathrm{N}$-alkylation, degree of $\mathrm{N}$-methylation, counterion type, and $\mathrm{pH}$. Importantly, the presence of QA-PEI nanoparticles in the studied dental composites did not negatively impact the degree of conversion in the composite matrix, nor its mechanical properties. In this review, we summarized these features and functions in order to present QA-PEI nanoparticles as modern and promising additives for dental materials that can impart unique antibacterial characteristics without deteriorating the products' structures or mechanical properties.
\end{abstract}

Keywords: dental composite restorative materials; antibacterial agents; quaternary ammonium polyethylenimine; nanoparticles

\section{Introduction}

Dental composite materials are most commonly used for restorative applications. They are primarily based on dimethacrylate monomers, including bisphenol A glycerolate dimethacrylate (Bis-GMA), an ethoxylated Bis-GMA derivative (Bis-EMA), triethylene glycol dimethacrylate (TEGDMA), and/or urethane dimethacrylate (UDMA) [1,2]. In fact, almost 75\% of dental composite materials contain Bis-GMA, and nearly 33\% of them contain Bis-GMA and UDMA [2] because of their advantageous physico-chemical, mechanical, and esthetic properties. However, dental plaque accumulation on their surfaces is greater than that on the surfaces of teeth as well as other restorative materials, such as glass-ionomer cements and amalgams. This is due to higher surface roughness, higher surface free energy, and lack of antibacterial activity [3-5]. Bacteria that are collected onto the reconstruction surface can survive in marginal gaps that are formed between the reconstruction and adjacent tissue due to polymerization shrinkage [6-8]. Secondary caries can occur as a result of bacterial metabolic processes, which are believed to be the main cause of dental restoration failure $[5,9,10]$. Therefore, it is necessary to develop dental composite materials with antibacterial properties. The simplest way to accomplish this is by modifying their 
matrices with bioactive compounds that are physically dispersed within them. It is reported that particles of inorganic compounds, such as zinc oxide [5,11,12], titanium dioxide [13,14], calcium phosphate [15,16], gold [17-20], and silver [17,18,21,22], as well as organic compounds, such as antibiotics [23], chlorhexidine [5,24,25], furanone [5], ursolic acid [5], benzalkonium chloride [5], triclosan [5], chitosan [5], and methacryloyloxydodecyl pyridinium bromide (MDPB) [5], can be used for this purpose. The latter compound represents a dynamically developing group of antibacterial agents that are based on quaternary ammonium salts [26-29]. Recently, nanoparticles made up of crosslinked quaternary ammonium polyethylenimine derivatives (QA-PEI) have gained the attention of scientists.

Polyethylenimine (PEI), also known as polyaziridine, is a synthetic polymer whose repeating unit consists of linearly-arranged secondary amine groups and ethylene groups. PEI can exist in two structural architectures, linear or branched. Linear PEI (LPEI) is obtained via acidic hydrolysis of poly (2-ethyl-2-oxazoline), and its chemical structure contains only secondary amino groups (the primary amine end groups can be neglected due to their small number) [30]. Branched PEI (BPEI) is obtained through cationic polymerization of aziridine and contains primary, secondary, and tertiary amino groups (Figure 1) [31]. The main difference between LPEI and BPEI is that LPEI is a solid at room temperature (RT), whereas BPEI is a liquid at RT. The melting point of LPEI is about $73-75^{\circ} \mathrm{C}$ and is soluble in chloroform, ethanol, methanol, and hot water at low $\mathrm{pH}$. In addition, relative to BPEI, LPEI is characterized by stable chemical properties [32]. As a result of these favorable features, LPEI is more commonly used.

a)<smiles>CCC(=O)N(C)CCC(O)CC(=O)NCCNCCCN</smiles>

b)

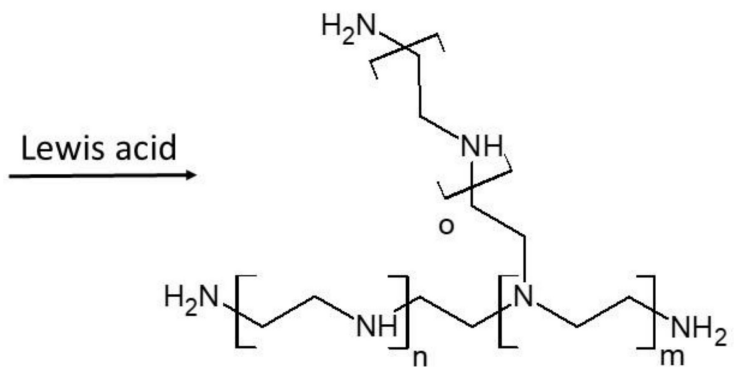

Figure 1. The synthesis of (a) linear polyethylenimine, (b) branched polyethylenimine. Adapted from [31].

PEI has many potential applications due to its polycationic character and water solubility [33]. In the biomedical field, it can be used as an antiviral agent in DNA transfection because it is able to interact with negatively charged DNA and RNA [33-36]. It is used for separation and purification of biomacromolecules, enzyme immobilization, biosensor construction, and drug delivery [33,37-42]. PEI can additionally be applied as a heavy metal removal agent during water treatment [43-47], a dye removal agent in the paper and textile industry [48-51], in alkaline ion-exchange membranes [52-55], and in $\mathrm{CO}_{2}$ adsorbents [30,56-59]. The amino groups in PEI are highly reactive and, thus, can be easily modified in order to obtain quaternary ammonium polyethylenimine derivatives [60]. The quaternized forms of PEI (QA-PEI) exhibit antibacterial activity against Gram-positive and Gram-negative bacteria; therefore, they can be used as biocides $[7,18,26,61,62]$. They are also known to be effective at inactivating enveloped viruses, such as HBV, HCV, HIV, and influenza viruses [26,63]. It is worth noting that the 
U.S. Environmental Protection Agency currently recommends 216 products containing quaternary ammonium compounds for use to inactivate the SARS-CoV-2 (COVID-19) virus [64].

Due to the amphiphilic character of the QA-PEI repeating unit, consisting of the quaternary nitrogen atom substituted with one major hydrophobic chain, QA-PEI can effectively be applied as an antibacterial agent $[25,30]$. The mechanism of its action includes causing the disfunction of the lipid bilayer membranes constituting the bacterial cytoplasmic membrane and the outer-membrane of Gram-negative bacteria $[25,65,66]$. Initially, the positively charged ammonium group interacts with the negatively charged bacterial cell walls and disturbs its electrical balance by displacing divalent cations, such as $\mathrm{Ca}^{2+}$. Further, the hydrophobic substituent interdigitates into the hydrophobic membrane core to decrease membrane fluidity. Finally, the membrane loses many of its osmoregulatory and physiological functions. It is manifested as a cellular leakage of potassium ions $\left(\mathrm{K}^{+}\right)$, protons, and other constituents of the cytoplasmic membrane, resulting in cell death [25,67-76]. In addition, the polycationic character of QA-PEI is responsible for its high antibacterial activity compared with low-molecular-weight antibacterial compounds [72,77]. All of these features make QA-PEI an attractive antibacterial agent for dental restorative composite materials.

Recent studies involving QA-PEI have focused on its crosslinked nanoparticulate forms. Such nanoparticles have been tested as antibacterial agents dispersed within the matrices of various dental materials used in restorative dentistry, orthodontics, prosthetics, endodontics, and oral implantology. The growing interest in dental nanomaterial applications for these nanoparticles is mainly due to their unique properties of nanoscale dimensions in combination with antibacterial activity $[17,18,78]$. Compared with micro- or macroparticles, nanoparticles are much more effective, and, therefore, they can be added in smaller quantities in order to achieve the desired function $[17,18,78,79]$. Additionally, by introducing QA-PEI nanoparticles into the dental materials, it is possible to achieve materials with antibacterial activity, while their original morphology and properties will be maintained.

This review comprehensively summarizes the results from several recent studies regarding (i) the synthesis of QA-PEI nanoparticles, (ii) their antibacterial activity as a function of chemical structure, (iii) the influence of incorporated QA-PEI nanoparticles on the antibacterial properties of various dental composite materials, and (iv) the impacts of incorporated QA-PEI nanoparticles on the macromolecular structure and mechanical properties of various dental composite materials.

\section{Synthesis of QA-PEI Nanoparticles}

QA-PEI nanoparticles are obtained from linear polyethylenimine. They were first synthesized by Beyth et al. [80] in 2006 via an N-alkylation method. This approach was later modified by Youdovin-Farber et al. [60] in 2010, who employed a reductive amination reaction.

Both processes include the following key steps:

1. Crosslinking: The goal of this process is to form PEI nanoparticles that consist of a crosslinked core with a large number of free-standing side chains. Due to the covalent bonding of the side chains, they represent an integral part of the core and cannot be dissociated [81]. The overall structure of a PEI nanoparticle contains primary, secondary, and tertiary amino groups. Primary amino groups are located at the ends of side chains, secondary amino groups are located within the core and the side chains, and tertiary amino groups are only located in the core. The difference between the two crosslinking methods is that, in the reductive amination process, glutaraldehyde is used as a crosslinking agent, whereas in the $\mathrm{N}$-alkylation process, crosslinking occurs using an alkyl dihalide, usually 1,5-dibromopentane (Figure 2) [60]. 1,4-dibromobutane and 1,6-dibromohexane can also be used as suitable crosslinking agents [82]. 


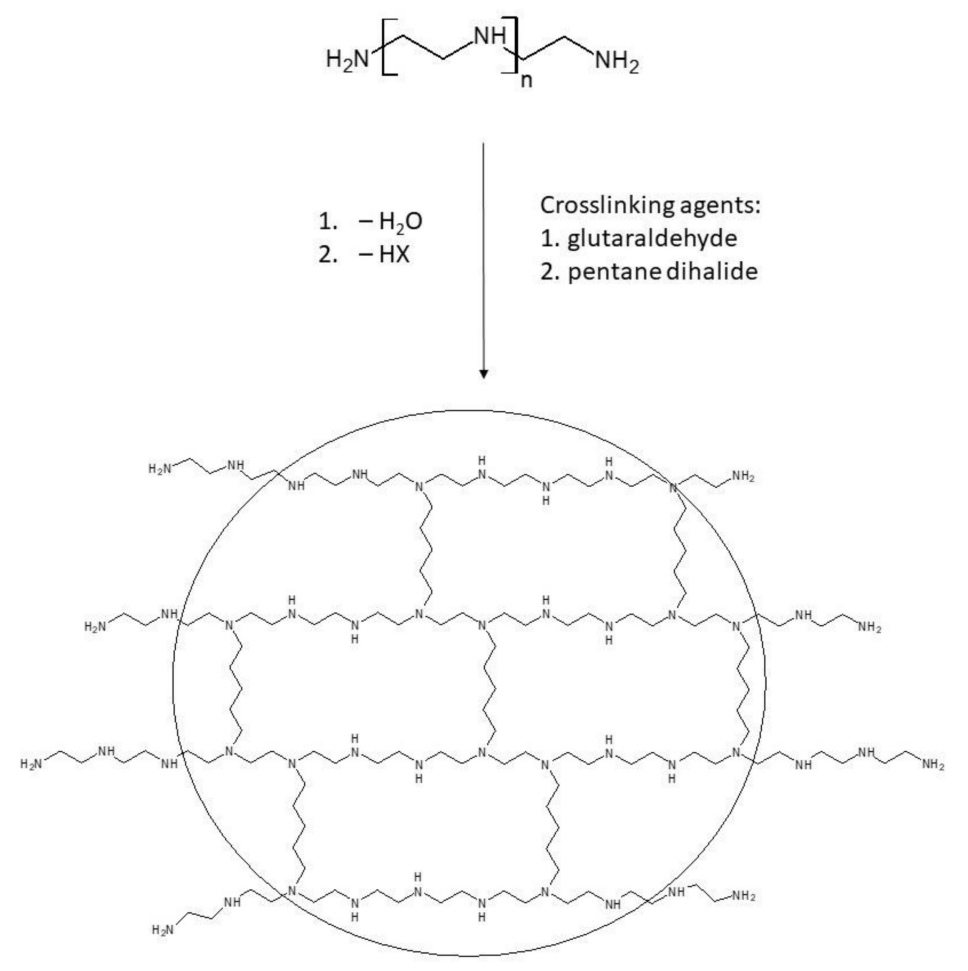

Figure 2. Formation of crosslinked polyethylenimine (PEI) nanoparticles. Adapted from [60].

It is recommended to use a crosslinker in amounts from 1 to 20 mol.\% [82]. The crosslink density influences the physico-chemical properties of QA-PEI nanoparticles. High crosslink density can cause an excessive stiffening of QA-PEI nanoparticles, decrease in their positive charge, and result in dimensions that are too large. This was demonstrated by Farah et al. [83], who performed crosslinking of PEI with the use of 1,5-diiodopentane in the amounts of 4, 8, and $12 \mathrm{~mol} \%$. An increase in the crosslink density resulted in the PEI stiffening, which was manifested by the increase in glass temperature $\left(\mathrm{T}_{\mathrm{g}}\right)$. Its value increased from 148 to $161^{\circ} \mathrm{C}$. Moreover, an increase in the crosslink density caused a decrease in the number of positively charged QA groups per surface area, and an increase in dimensions of nanoparticles (nanoparticles of $30 \mu \mathrm{m}$ in diameter were generated when $12 \%$ of crosslinker was used). The crosslinker content did not influence the hydrophobicity of QA-PEI nanoparticles.

2. Telomerization: This step aims to extend the side chains by adding long linear alkyl chains, which are crucial for defining the hydrophobic character of the nanoparticles. In fact, hydrophobicity governs the interactions of QA-PEI nanoparticles with lipids located in bacterial cell walls. The telomerization process involves the transformation of primary amino groups into secondary amino groups. Alkyl bromide is often used for this purpose in the $\mathrm{N}$-alkylation method (Figure 3), whereas octanal is used in the reductive amination method (Figure 4). 

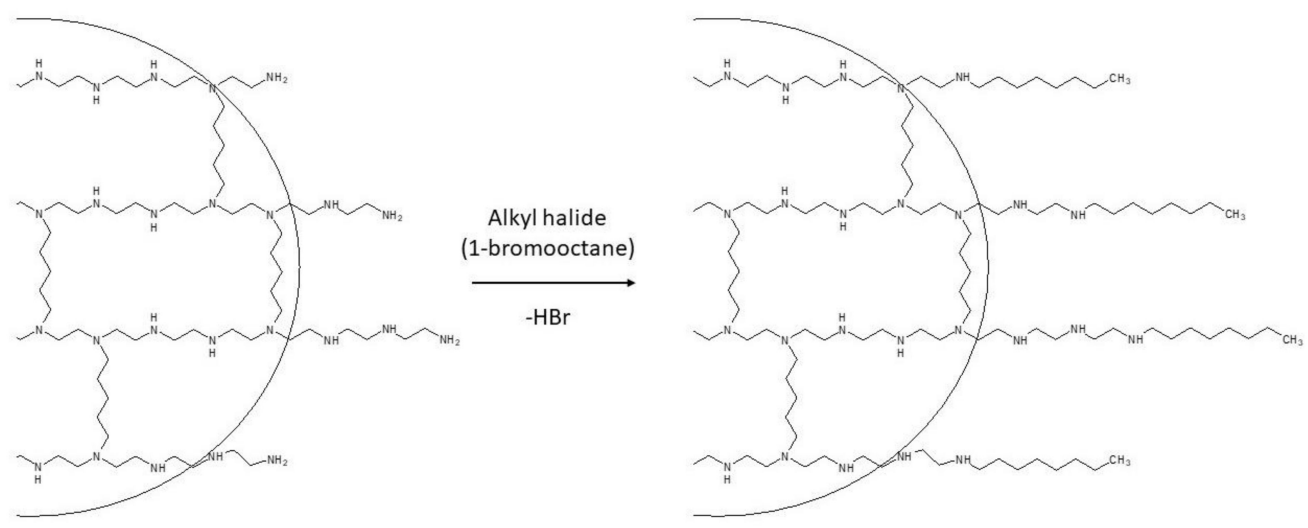

Figure 3. Telomerization in the $\mathrm{N}$-alkylation method with the use of 1-bromooctane. Adapted from [60].
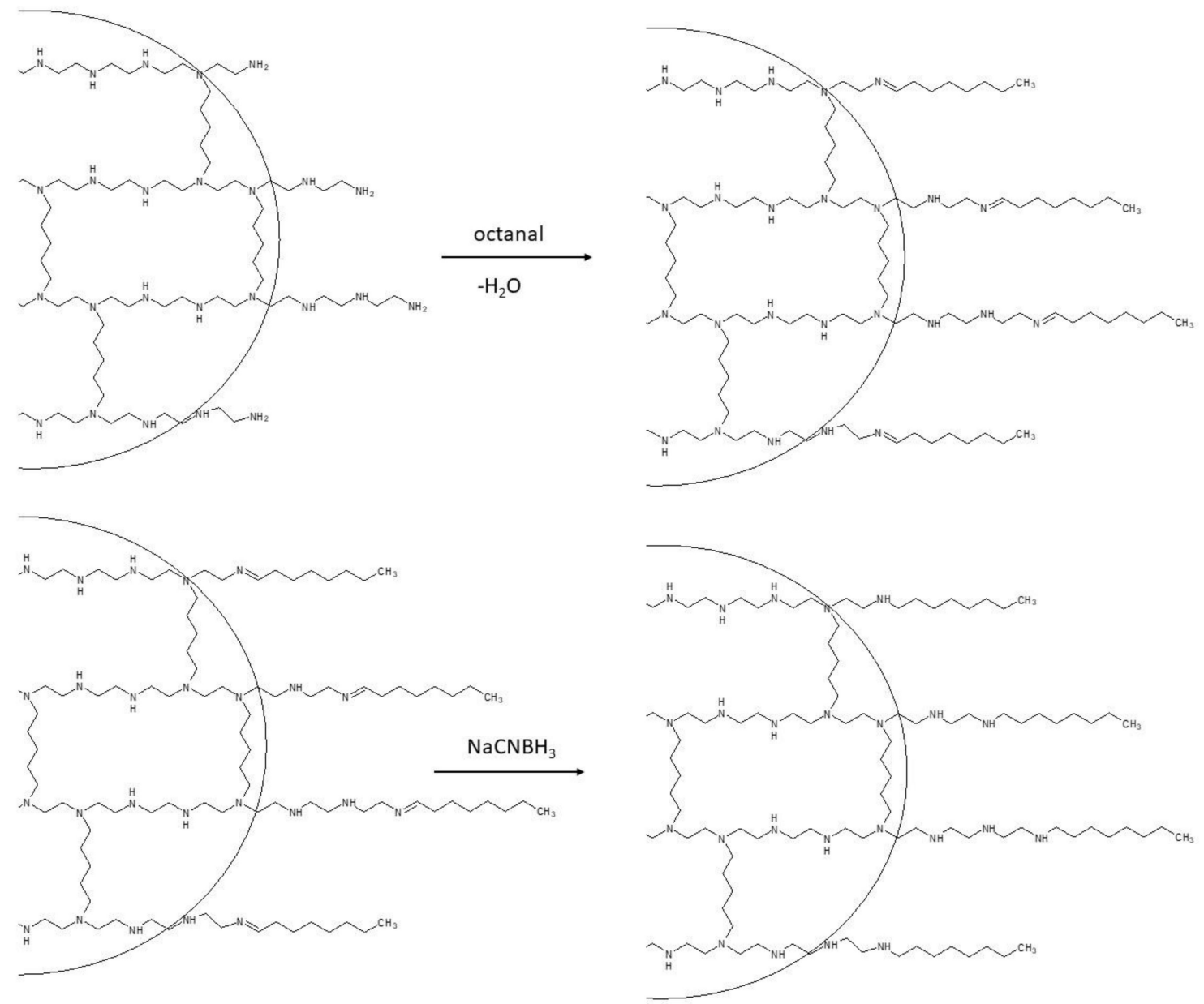

Figure 4. Telomerization in the reductive amination method with the use of octanal. Adapted from [60].

The reductive amination method requires an additional step, which involves the reduction of the double bonds that are formed during the reaction of the primary amino groups with octanal. Sodium cyanoborohydride $\left(\mathrm{NaCNBH}_{3}\right)$ is used in this reaction as a reducing agent (Figure 4) [60,82].

Octyl bromide is the most often used N-alkylation agent $[60,84,85]$. Butyl bromide [85], hexyl bromide [85,86], decyl bromide [85,86], dodecyl bromide [84], hexadecyl bromide [84,85], and $\alpha$-bromotoluene [86] may also be used as suitable $\mathrm{N}$-alkylation agents.

It is recommended to determine the primary amine content after this stage, which could be performed utilizing the trinitrobenzene sulfonic acid (TNBS) method [87]. 
The important aspect of this stage is the neutralization of hydrogen bromide $(\mathrm{HBr})$, which is formed in the $\mathrm{N}$-alkylation method. Typically, sodium bicarbonate $\left(\mathrm{NaHCO}_{3}\right)$ is used for this purpose [60]. Zaltsman et al. [88] tested the influence of variations in the $\mathrm{N}$-alkylation stage on the manufacturing process of QA-PEI nanoparticles. Those variations included (i) the controlled neutralization of hydrogen iodide with a minimal amount of $\mathrm{NaHCO}_{3}$; (ii) in the case of excess $\mathrm{NaHCO}_{3}$, the neutralization of the base with strong hydrochloric and phosphoric acids; (iii) treatment with surfactants $N$-lauroylsarcosine or glycerol monostearate. The application of glycerol monostearate resulted in the formation of fibrous QA-PEI derivatives; therefore, this could not be considered further. The efficiency of all other methods was assessed by testing the total bacterial growth inhibition on the surface of the dimethacrylate-based dental restorative material (Filtek Supreme XT) modified with QA-PEI nanoparticles. The highest antibacterial activity was achieved for the standard neutralization procedure and those involving phosphoric acid and N-lauroylsarcosine surfactant. The total bacterial growth inhibition for them was achieved with a content of $0.5 \mathrm{wt} . \%$ QA-PEI nanoparticles. A greater amount of QA-PEI nanoparticles, corresponding to $1 \mathrm{wt} . \%$, was required to achieve total bacterial growth inhibition with QA-PEI nanoparticles obtained via controlled neutralization and the application of hydrochloric acid. The findings lead to the conclusion that the standard method of the $\mathrm{HBr}$ neutralization can be recommended. Tested modifications are of no particularly great benefit as they require the application of additional reagents, which is not accompanied by an increase in the antibacterial activity.

3. Quaternization: This process results in the generation of quaternary ammonium groups. Specifically, the procedure targets secondary and tertiary amino groups that can react with an alkyl halide, which functions as the quaternization agent. Since iodomethane is typically used for this purpose, this step is also called $N$-methylation (Figure 5) [60]. The quaternization of amine groups is responsible for instilling the QA-PEI nanoparticles with their antibacterial properties. This stage is also crucial for determining the intensity of their antibacterial activity $[60,85,86]$.
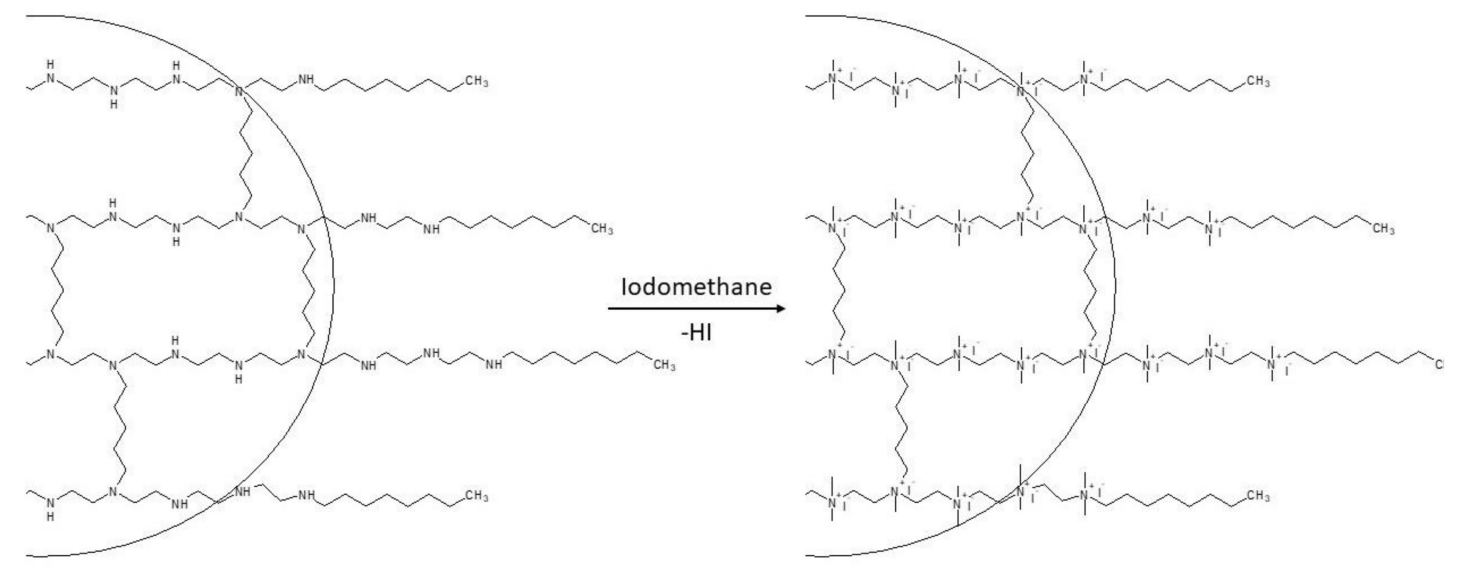

Figure 5. The quaternization step that occurs in both methods. Adapted from [60].

The synthesis of QA-PEI nanoparticles is typically carried out in polar, anhydrous solvents. Absolute ethyl alcohol (anhydrous) is the most commonly used because it is highly polar and can prevent precipitation of nanoparticles, which often occurs in the presence of moisture.

The original $N$-alkylation method of QA-PEI nanoparticle synthesis has been proven to be the easiest and least time-consuming; therefore, this approach is more commonly used [80,83-86,88-98] than the reductive amination [60].

QA-PEI nanoparticles prepared via the reductive amination and $N$-alkylation methods can differ in diameter $[60,82,83]$. According to its U.S. patent, QA-PEI nanoparticles in sizes between 30 and 150 $\mathrm{nm}$ are the most preferable. However, nanoparticles smaller than $1000 \mathrm{~nm}$ are also acceptable [82]. 
The length and content of the $N$-alkylation agent influence the QA-PEI nanoparticles' size. For example, it was found that complete $\mathrm{N}$-alkylation using octyl bromide resulted in the formation of QA-PEI nanoparticles with the apparent particle size of 24 and $40 \mathrm{~nm}$, respectively [60]. A decrease in the octyl halide content resulted in an increase in the QA-PEI nanoparticles' dimensions. For example, QA-PEI nanoparticles alkylated with $25 \mathrm{~mol}$ \% of octyl halide with respect to PEI units were characterized by a particle size from 160 to $190 \mathrm{~nm}$ [83]. The increase in the $N$-alkylation agent length also caused an increase in the nanoparticle size [85]. An increase in the $N$-alkyl substituent length from 4 to 10 carbon atoms resulted in an increase in the QA-PEI nanoparticles' diameter from 200 to $500 \mathrm{~nm}$.

These findings lead to the conclusion that QA-PEI nanoparticles can be effectively synthesized via the $\mathrm{N}$-alkylation method, show inhibition of bacterial growth, and, therefore, could be used as antibacterial additives for biomedical devices [60]. However, the recognition that the antibacterial activity of QA-PEI nanoparticles is governed by particular elements of their chemical structure has initiated a research path exploring the relationships between the chemical structure of QA-PEI nanoparticles and their biocidal properties.

\section{Antibacterial Properties of QA-PEI Nanoparticles}

Many studies have shown that QA-PEI nanoparticles exhibit antibacterial activity against various strains of bacteria. Their biocidal properties have been examined against Gram-positive bacteria (Actinomyces viscosus [92,93], Enterococcus faecalis [83,88,90,93], Lactobacillus casei [93], Staphylococcus aureus [60,84,90], Staphylococcus epidermidis [90], Streptococcus mutans [80,85]), as well as Gram-negative bacteria (Escherichia coli $[36,90]$ and Pseudomonas aeruginosa $[84,86,90]$ ).

The antibacterial properties of QA-PEI nanoparticles are significantly affected by the reagent types and quantities used in their synthesis. The choice of reagents ultimately governs various structural parameters of QA-PEI nanoparticles, including the degree of crosslinking, telomere length, degree of telomerization, degree of quaternization, and counterion type. The antibacterial properties of QA-PEI nanoparticles can also be affected by environmental factors, such as $\mathrm{pH}$ or the presence of oxidizing agents.

QA-PEI nanoparticles are usually tested for antimicrobial activity $(A)$, which can be calculated according to the following equation:

$$
A=\log B_{0}-\log \frac{\sum_{i=1}^{n} B_{i}}{n}
$$

where $\log B_{0}$ is the initial suspension concentration (in CFU/mL; CFU—colony forming units), $B_{i}$ is the suspension concentration after incubating with QA-PEI samples (in CFU/mL), and $n$ represents the number of replicated tests.

\subsection{Crosslink Density}

Crosslinking is the first step in QA-PEI nanoparticle synthesis, and it is responsible for creating the nanoparticulate form, causing insolubility [90], and generating "non-leaching" antimicrobial polymers [80,83].

The crosslinking agent type and crosslink density influence the antibacterial activity of QA-PEI nanoparticles.

The effect of the crosslinking agent on the antimicrobial activity of QA-PEI nanoparticles against Gram-positive (S. aureus) and Gram-negative (P. aeruginosa) bacteria was shown in the work of Nuzhdina et al. (Table 1) [84]. The following crosslinking agents were used for this purpose: ethylene glycol bis(chloroacetate), diethylene glycol bis(chloroacetate), triethylene glycol bis(chloroacetate), polyethylene glycol bis(chloroacetate), 1,5-dibromopentane, and glutaraldehyde. All of them were applied at the constant mole ratio of PEI monomer units to crosslinking agent, which was 1:0.04. 
Table 1. The influence of the crosslinker type on the antimicrobial activity of quaternary ammonium polyethylenimine (QA-PEI) nanoparticles against S. aureus and P. aeruginosa. Data from [84].

\begin{tabular}{cccc}
\hline \multirow{2}{*}{ Alkyl Bromide. } & Crosslinking Agent & \multicolumn{2}{c}{ Antibacterial Activity ${ }^{\mathbf{1}}$} \\
\cline { 3 - 4 } & & S. aureus & P. aeruginosa \\
\hline & Ethylene glycol bis(chloroacetate) & 3.2 & $<1.5$ \\
& Diethylene glycol bis(chloroacetate) & 3.4 & $<1.5$ \\
& Triethylene glycol bis(chloroacetate) & 3.6 & $<1.6$ \\
1-bromohexadecane & Polyethylene glycol bis(chloroacetate) & 3.8 & $<1.7$ \\
& 1,5-Dibromopentane & 2.1 & $<1.5$ \\
& Glutaraldehyde & 2.4 & $<1.5$ \\
\hline
\end{tabular}

${ }^{1}$ Antibacterial activity was calculated using Equation (1).

As can be seen from Table 1, the QA-PEI nanoparticles showed antibacterial activity against S. aureus. Its value depended on the bacteria class and crosslinker type.

It is not surprising that tested QA-PEI nanoparticles demonstrate low antibacterial activity against P. aeruginosa [84]. This is a highly pathogenic strain of Gram-negative bacteria. This bacteria is characterized by the bilayer structure of its cell membrane, which is built of rigid lipopolysaccharides and makes them highly resistant to many antimicrobial agents [99-101].

The antibacterial activity of QA-PEI nanoparticles also depends on the hydrophilic character of the crosslinker [84]. For example, the glycol-based crosslinkers, which are more hydrophilic than commonly used 1,5-dibromopentane and glutaraldehyde, displays more efficient antibacterial activity. Additionally, an increase in the antibacterial activity is observed with the increase in the crosslinker oligooxyethylene chain length. It is well known that increasing the length of the oligooxyethylene chain results in an increase in its elasticity and the same occurs with the increase in polymer network elasticity [102]. Therefore, it can be assumed that the antibacterial activity of the QA-PEI nanoparticles depends on the elasticity of the polymer network, constituting their cores. The greater the core elasticity, the greater the antibacterial activity.

The antibacterial activity of QA-PEI nanoparticles is also influenced by the crosslink density. The higher the concentration of the crosslinking agent, the lower the antibacterial activity. This can be linked to the increasing nanoparticle core stiffness (an increase in $T_{g}$ is observed with an increase in crosslink density $[83,102])$. The effect of the crosslink density on the antibacterial activity of QA-PEI nanoparticles was shown by Nuzhdina et al. [84]. They observed that an increase in the content of ethylene glycol bis(chloroacetate), used as a crosslinker in a molar ratio ranging from 0.02 to 0.10 with respect to PEI monomer units, caused a decrease in the antibacterial activity against $S$. aureus as well as P. aeruginosa (Table 2).

Youdovin-Farber et al. [85] confirmed that antibacterial activity decreased as the crosslink density increased and additionally revealed that insufficient crosslink density could cause a decrease in the antibacterial activity of QA-PEI nanoparticles. The crosslinking was performed with 1,5-dibromopentane at concentrations of $0.01,0.04$, and 0.2 mole fraction with respect to PEI monomer units. The antibacterial activity of the resulting QA-PEI nanoparticles was evaluated by determining the bacterial growth (\%) of $S$. mutans on a restorative composite resin enriched with $1 \mathrm{wt} . \%$ QA-PEI nanoparticles. The QA-PEI nanoparticles of moderate crosslink density, corresponding to $4 \mathrm{~mol} \%$ of the crosslinker, displayed the most effective antibacterial action (bacterial growth on the modified composite corresponded to $0.2 \%$ ). In contrast, QA-PEI nanoparticles synthesized using 1 and $2 \mathrm{~mol} . \%$ of the crosslinker inhibited bacterial growth 330 and 75 times less efficiently, respectively (i.e., bacterial growth on the modified composite corresponded to $66 \%$ and $15 \%$, respectively). The weakest bacterial growth inhibition, exhibited by nanoparticles of the lowest crosslink density, could be attributed to the insufficient crosslink density, which led to the separation of the polymer chains. In the case of the QA-PEI nanoparticles with the highest crosslink density, the nanoparticles' core was probably too stiff, 
so their interaction with the bacterial membrane was reduced, and the antibacterial activity of the sample decreased.

To conclude, it is clear that the crosslink density in the core of QA-PEI nanoparticles strongly influences their antibacterial activity and must be carefully examined to design nanoparticles with optimal performance. A crosslink density that is either too large or too small may have detrimental effects.

Table 2. Antibacterial activity of QA-PEI nanoparticles prepared with the ethylene glycol bis(chloroacetate) crosslinker and different alkylation agent chain lengths against $S$. aureus and P. aeruginosa. Data from [84].

\begin{tabular}{ccccc}
\hline \multirow{2}{*}{ Alkyl Bromide } & Crosslinking & Crosslinking & \multicolumn{2}{c}{ Antibacterial Activity } \\
\cline { 3 - 4 } & Agent & Ratio & S. aureus & P. aeruginosa \\
\hline \multirow{3}{*}{ 1-bromooctane } & & $1: 0.02$ & $>6$ & 5.0 \\
& Ethylene glycol & $1: 0.04$ & $>6$ & 4.3 \\
& bis(chloroacetate) & $1: 0.06$ & $>6$ & 3.8 \\
& & $1: 0.08$ & 4.8 & 2.5 \\
& & $1: 0.1$ & 4.6 & $<1.8$ \\
\hline \multirow{3}{*}{ 1-bromododecane } & & $1: 0.02$ & 4.9 & 1.6 \\
& & $1: 0.04$ & 4.4 & $<1.5$ \\
& Ethylene glycol & $1: 0.06$ & 4.2 & $<1.5$ \\
& bis(chloroacetate) & $1: 0.08$ & 3.7 & $<1.5$ \\
& & $1: 0.1$ & 3.3 & $<1.5$ \\
\hline \multirow{2}{*}{ 1-bromohexadecane } & & $1: 0.02$ & 3.5 & $<1.5$ \\
& & $1: 0.04$ & 3.2 & $<1.5$ \\
& & $1: 0.06$ & 2.8 & $<1.5$ \\
& Ethylene glycol & $1: 0.08$ & 2.6 & $<1.5$ \\
& & $1: 0.1$ & 1.8 & $<1.5$ \\
\hline
\end{tabular}

${ }^{1}$ Antibacterial activity was calculated using Equation (1).

\subsection{Length of N-alkyl Telomers}

QA-PEI nanoparticles contain long side chains with alkyl telomeres at the ends [60,80,82]. These telomeres originate from $\mathrm{N}$-alkylation (using alkyl halides) of the side chains that protrude from the crosslinked PEI core. Alkyl bromides are used in most cases because of their high reactivity in nucleophilic substitution reactions, which is related to their acidity (more reactive than alkyl chlorides and alkyl fluorides, but less reactive than alkyl iodides). During the nucleophilic substitution, the nucleophile (in this case, an amine) displaces the leaving group of an acyl derivative (in this case, an alkyl halide). As the nucleophile takes the place of the leaving group, the reactivity of the acyl derivative depends on the propensity of the halogen group to leave. Weak bases (anions of strong acids) are better leaving groups than strong bases. Since hydroiodic and hydrobromic acids are much stronger acids than hydrofluoric or hydrochloric acids, the iodide and bromide anions represent better leaving groups than fluoride and chloride anions; therefore, they have higher reactivity in nucleophilic substitution reactions $[103,104]$.

PEI is hydrophilic, and alkyl chains are hydrophobic, so the $N$-alkylation process decreases the hydrophilicity of QA-PEI nanoparticles. Longer alkyl bromide chains and greater quantities of introduced alkyl bromide both lead to stronger hydrophobic character in the resulting QA-PEI nanoparticles [81]. Hydrophobic character is crucial for the antibacterial efficiency of QA-PEI nanoparticles because after diffusing through the bacterial cell wall, antibacterial agents with hydrophobic moieties can bind to the cytoplasmic membrane [25,72]. For this reason, the relationship between the length of alkyl bromides used and the resulting antibacterial properties of QA-PEI nanoparticles requires detailed understanding. 
The results of several studies show that the antibacterial activity of QA-PEI nanoparticles is strongly affected by the $\mathrm{N}$-alkyl chain length. It increases with the increasing length of the alkyl telomere from four-carbon chains up to eight-carbon chains. However, increasing the alkyl chain length any further reduces the antibacterial activity of the QA-PEI nanoparticles.

Nuzhdina et al. [84] showed that QA-PEI nanoparticles with octyl and dodecyl telomeres exhibited significantly higher antibacterial activity against $S$. aureus relative to nanoparticles containing hexadecyl telomers. QA-PEI nanoparticles obtained with 1-bromooctane and 1-bromododecane attained CFU/mL values on the order of $1 \times 10^{6}$, whereas those obtained with 1-bromohexadecane had $50 \%$ lower $\mathrm{CFU} / \mathrm{mL}$ values $\left(5 \times 10^{5}\right)$. In the same study, the antibacterial activity of QA-PEI nanoparticles was also calculated using Equation (1). The data presented in Figure 6 shows that the use of 1-bromooctane as the $\mathrm{N}$-alkylation agent resulted in QA-PEI nanoparticles with the highest antibacterial activity.

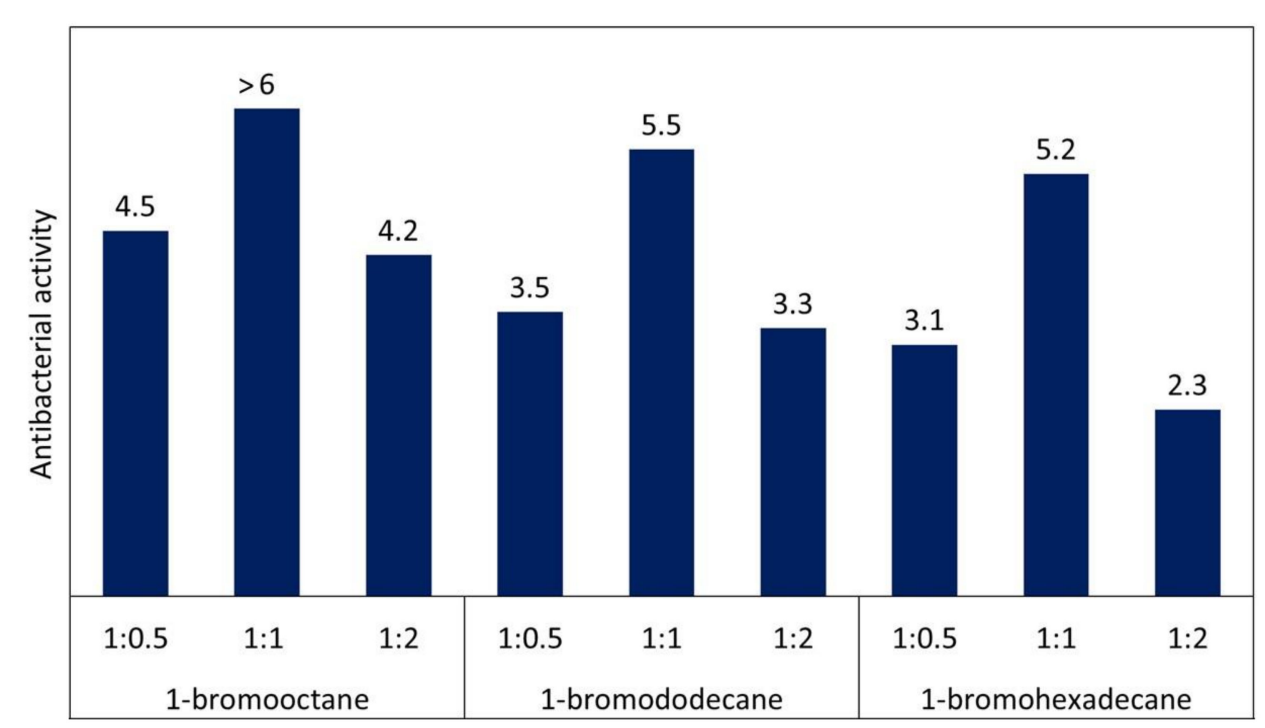

Figure 6. Antibacterial activity of QA-PEI nanoparticles alkylated with different $N$-alkylation agents and with various degrees of $N$-alkylation. Data from [84].

Youdovin-Farber et al. [85] showed the detailed relationship between the antibacterial efficiency of QA-PEI nanoparticles and $N$-alkyl chain length. The presence of the 4-carbon chain resulted in very low antibacterial efficiency. The extension of the $N$-alkyl substituent, having 6 and 8 -carbon chains, resulted in a radical increase in the antibacterial efficiency, and it reached a maximum for the 8-carbon chain. Further increase in the $N$-alkyl chain length resulted in a radical decrease in the antibacterial efficiency of QA-PEI nanoparticles. The QA-PEI nanoparticles obtained using 1-bromooctane inhibited the growth of $S$. mutans almost 800 times better than those obtained using 1-bromobutane, and almost 900 times better than those obtained using 1-bromohexadecane (Figure 7).

By testing the microbiological activity of the linear QA-PEIs, Yew et al. [86] confirmed that the longer the $\mathrm{N}$-alkyl chain, the weaker the antibacterial action. The QA-PEI modified with 1-bromohexane exhibited greater antibacterial activity than that modified with 1-bromodecane. The minimum inhibitory concentration (MIC) values of QA-PEI with decyl telomeres was almost five times higher than that of QA-PEI with hexyl telomeres in the tests against $S$. aureus and about 14 times higher in the tests against P. aeruginosa (Figure 8). Yew et al. [86] also showed that the utilization of aryl halide ( $\alpha$-bromotoluene), instead of the aliphatic $N$-alkylation agent, resulted in high antibacterial efficiency of the QA-PEI, which was comparable to that of the QA-PEI modified with 1-bromohexane. 


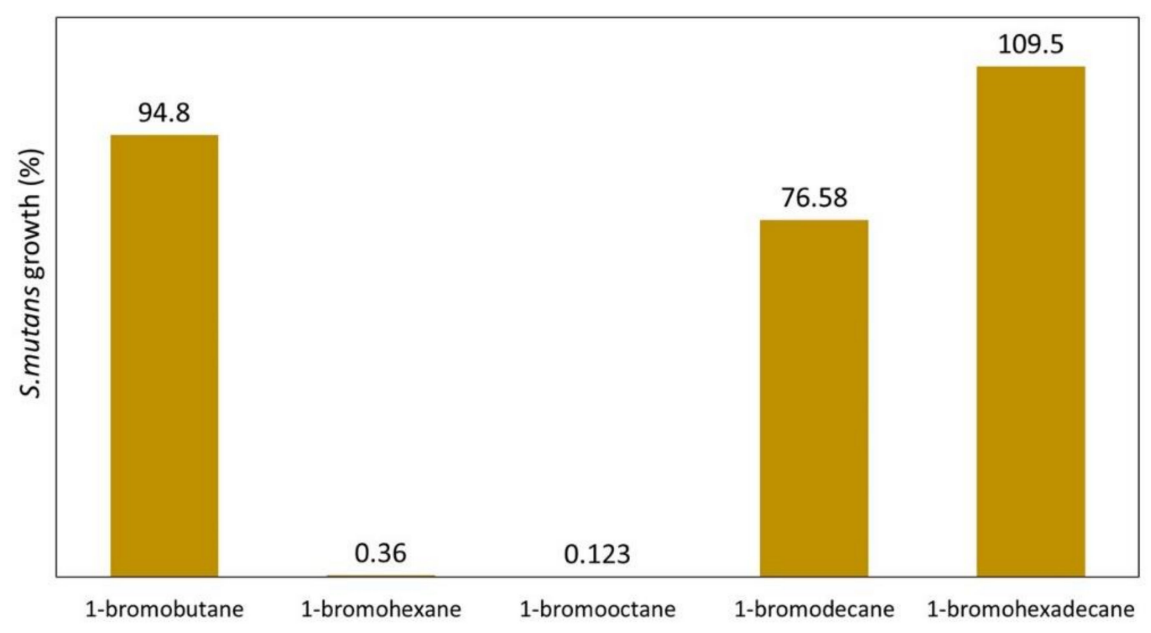

Figure 7. S. mutans growth (\%) on the surface of a commercial dental composite enriched with 1 wt.\% QA-PEI nanoparticles, which were telomerized using alkyl bromides of various lengths. Data from [85].

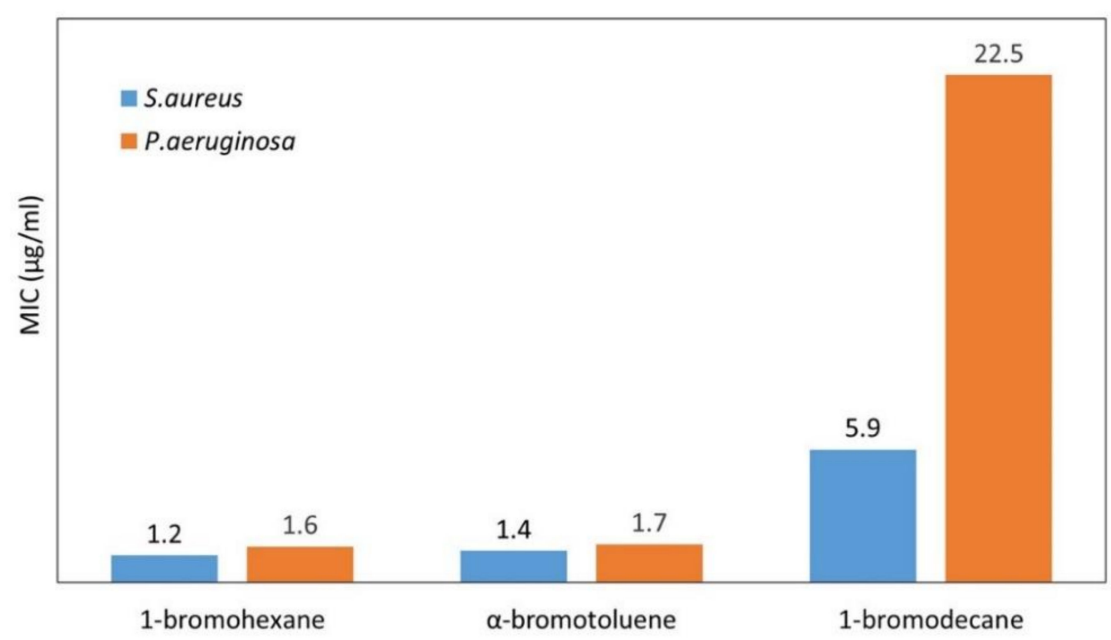

Figure 8. The minimum inhibitory concentration (MIC) $(\mu \mathrm{g} / \mathrm{mL})$ values of fully quaternized linear QA-PEIs obtained using various bromides and tested against $S$. mutans and P. aeruginosa. Data from [86].

From the above, it is seen that octyl substituent results in the highest antibacterial activity of QA-PEI nanoparticles. $N$-alkyl substituents, which have less or more than eight carbon atoms, decrease antibacterial activity. The finding is in agreement with the literature data on the general antibacterial activity of quaternary ammonium compounds [25], which says that compounds with $N$-alkyl chain lengths of less than 4 and more than 18 carbon atoms are virtually inactive.

The poor antibacterial activity of QA-PEI nanoparticles obtained with bromobutane is likely due to their insufficient hydrophobicity, in addition to the fact that short alkyl chains are not able to effectively interact with bacterial cells' lipids [85].

QA-PEI nanoparticles with excessively long telomeres have increased hydrophobic character and, therefore, they also exhibit reduced antibacterial activity. Long, hydrophobic telomeres impart an amphiphilic character, which results in an increased tendency to form micelles. Such micellization decreases the ability of QA-PEI nanoparticles to lyse bacterial cells, thereby reducing their antibacterial activity [86]. Alternatively, steric effects caused by the long alkyl chains may also influence their activity. If there are more than eight carbon atoms in the telomers, the positively charged quaternary nitrogen atoms might be screened, thus reducing their interactions with negatively-charged bacterial cell walls [84]. Finally, longer telomeres are capable of adhering to one another via hydrophobic intermolecular interactions, which may also hinder the access of the nitrogen atoms $[85,86]$. 


\subsection{Degree of N-Alkylation}

The antibacterial properties of QA-PEI nanoparticles strongly depend on the degree of $N$-alkylation, also called the degree of telomerization, which is determined by the molar ratio of the telomerization agent to PEI units. A larger molar fraction of the telomerization agent leads to a greater number of primary amino groups that are converted to secondary amino groups, which is the metric of the degree of $\mathrm{N}$-alkylation. A higher degree of $\mathrm{N}$-alkylation indicates an increase in the hydrophobic character of the QA-PEI nanoparticles, which enables favorable interactions with the lipids of bacterial cell walls [25]. Therefore, the higher the degree of $N$-alkylation, the higher the antibacterial activity of QA-PEI nanoparticles $[60,84,85]$. A low degree of $N$-alkylation decreases the hydrophobic character of QA-PEI nanoparticles, so their ability to bind with the cytoplasmic membrane after diffusing through the bacterial cell walls is lower, thus decreasing their antibacterial efficiency [25]. Therefore, incomplete $\mathrm{N}$-alkylation usually leads to insufficient antibacterial activity of QA-PEI nanoparticles $[60,84,85]$. On the other hand, the application of excessive amounts of $\mathrm{N}$-alkylation agent has the same negative effect [84].

Youdovin-Farber et al. [60] showed that the antibacterial efficiency of QA-PEI nanoparticles increased with an increasing degree of $N$-alkylation by using octanal as the $N$-alkylation agent in molar fractions with respect to PEI units ranging from 0.25 to 1 (Figure 9). The QA-PEI nanoparticles obtained with 75 and 100 mol.\% of octanal inhibited bacterial growth at concentrations four times lower than nanoparticles obtained with $25 \mathrm{~mol} \%$ of octanal. This result indicates that a $75 \mathrm{~mol} \%$ content of the $\mathrm{N}$-octyl substituent relative to PEI unit is sufficient to achieve a satisfactory antibacterial effect against S. aureus, and that increasing this mole fraction any further adds no benefit.

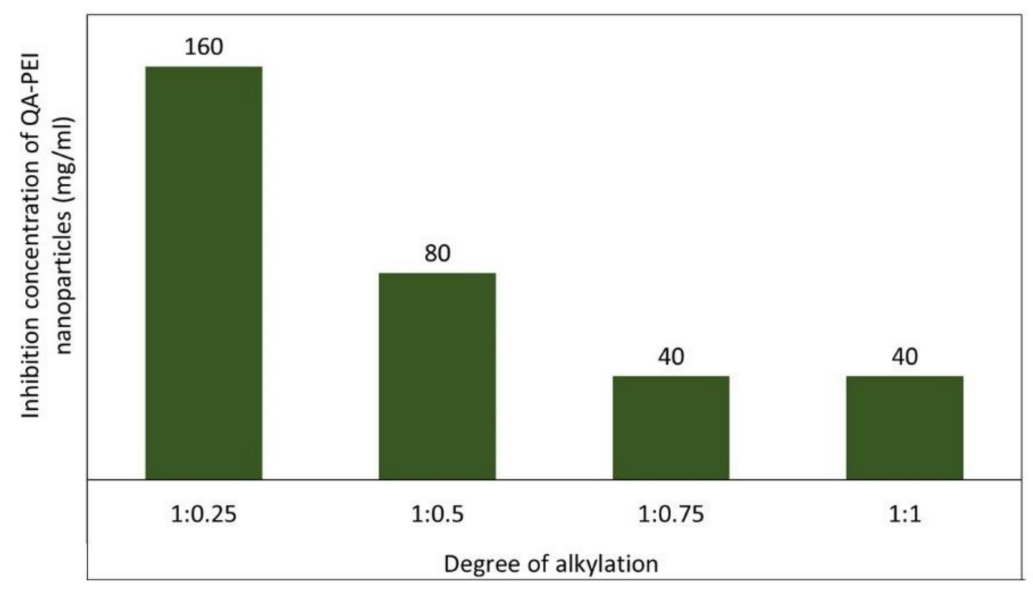

Figure 9. Concentration of QA-PEI nanoparticles $(\mathrm{mg} / \mathrm{mL})$ with varying degrees of telomerization required for complete inhibition of $S$. aureus growth. Data from [60].

Youdovin-Farber et al. [85] showed that incomplete telomerization negatively affected the antibacterial efficiency of QA-PEI nanoparticles. The antibacterial efficiency was tested against S. mutans by the modification of a restorative composite with $1 \mathrm{wt}$ \% QA-PEI nanoparticles and determination of bacterial growth (\%) onto a composite surface. The completely-telomerized QA-PEI nanoparticles (1:1 mol/mol PEI units/bromooctane) were almost six times more efficient in inhibiting the growth of $S$. mutans compared to those telomerized at $25 \%$. The $1: 1 \mathrm{~mol} / \mathrm{mol}$ PEI units/bromooctane mole ratio resulted in $0.123 \%$ bacterial growth on the investigated surfaces, whereas the mole ratio 1:0.25 resulted in $0.7 \%$ bacterial growth.

Nuzhdina et al. [84] also showed that a low degree of telomerization led to insufficient antibacterial activity of the QA-PEI nanoparticles. Additionally, they showed that the utilization of excessive amounts of the $\mathrm{N}$-alkylation agent resulted in decreased antibacterial activity of QA-PEI nanoparticles. In their study, QA-PEI nanoparticles were telomerized using three different alkyl bromides (having 
8, 12, or 16-carbon chains) added in various mole ratios of PEI units to alkyl bromide (1:0.5, 1:1, or 1:2). The greatest antibacterial activity of QA-PEI nanoparticles (against $S$. aureus) was achieved with a stoichiometric amount of alkyl bromide $(1: 1 \mathrm{~mol} / \mathrm{mol})$ in each series (Figure 6). Further, within the most bioactive series (employing bromooctane), the use of a $1: 1 \mathrm{~mol} / \mathrm{mol}$ ratio of PEI units/bromooctane increased the antibacterial efficiency by $33 \%$ and $43 \%$ relative to the 1:0.5 and 1:2 $\mathrm{mol} / \mathrm{mol}$ ratios, respectively. In the least bioactive series (employing bromohexadecane), complete telomerization with a $1: 1 \mathrm{~mol} / \mathrm{mol}$ ratio of PEI units/bromohexadecane induced the most dramatic increase in antibacterial efficiency. Its value was $68 \%$ and $126 \%$ greater than the $1: 0.5$ and $1: 2 \mathrm{~mol} / \mathrm{mol}$ ratios of PEI units/bromohexadecane, respectively.

\subsection{Degree of Quaternization}

Quaternization is the final step in the manufacturing process of QA-PEI nanoparticles. This procedure involves the reaction between the tertiary nitrogen atom resulting from $\mathrm{N}$-alkylation and methyl iodide to form quaternary ammonium salt. When the permanently-charged quaternary ammonium cation is formed, the PEI derivative gains its antimicrobial activity, the intensity of which depends on the amount of methyl iodide used in the reaction. In general, a higher mole fraction of methyl iodide leads to a greater degree of cationization (a greater number of quaternary ammonium cations) and a greater ability of the QA-PEI derivatives to interact with negatively-charged bacterial cell surfaces [36].

The $N$-methylation has a significant influence on the QA-PEI nanoparticles' antibacterial properties. The methylated form of QA-PEI nanoparticles inhibit bacterial growth several times more efficiently than their non-methylated counterparts. The study of Youdovin-Farber et al. [85] revealed this difference. They tested the antibacterial activity of a restorative composite enriched with $1 \mathrm{wt} . \%$ of methylated or non-methylated QA-PEI nanoparticles, having octyl and hexyl telomers, against S. mutans. The methylated forms of QA-PEI nanoparticles inhibited bacterial growth (\%) almost 300 times and 200 times more efficiently than their non-methylated counterparts, respectively (Figure 10).

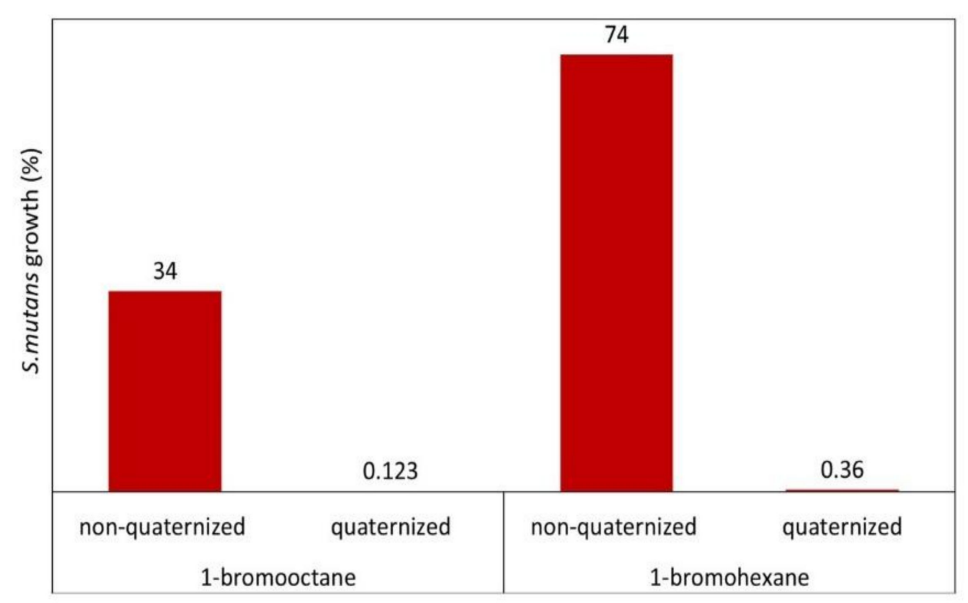

Figure 10. S. mutans growth (\%) on the surface of a restorative composite resin containing $1 \mathrm{wt} . \%$ quaternized and non-quaternized QA-PEI nanoparticles. Data from [85].

The results of another study by Youdovin-Farber et al. [60] revealed that QA-PEI nanoparticles gain antibacterial activity at a particular degree of quaternization. An insufficient methylation degree obstructed the antibacterial activity of QA-PEI nanoparticles. In the study, QA-PEI nanoparticles with octyl telomeres were subjected to quaternization using methyl iodide. The mole ratio of the PEI monomer units to methyl iodide ranged from 1:1 to 1:3. QA-PEI nanoparticles obtained using either 1:1 or 1:2 mole ratios did not show antibacterial activity against $S$. aureus at concentrations up to $80 \mu \mathrm{g} / \mathrm{mL}$, suggesting an insufficient degree of $N$-methylation. However, the QA-PEI nanoparticles obtained 
using a 1:3 $\mathrm{mol} / \mathrm{mol}$ ratio (monomer units of $\mathrm{PEI} /$ methyl iodide) completely inhibited bacterial growth at a concentration of $80 \mu \mathrm{g} / \mathrm{mL}$.

The studies on linear QA-PEI suggest that the antibacterial activity of QA-PEI nanoparticles can result from the combined effect of the quaternization degree, $\mathrm{N}$-alkylation agent, and bacteria strain. Randomly chosen reactants can strongly limit antibacterial activity. On the other hand, a carefully selected combination of reactants supported with microbiological tests can trigger antibacterial activity against a particular bacteria strain.

Yew et al. [86] showed the combined influence of the degree of quaternization and telomere type on the antibacterial efficiency of the linear QA-PEI against $S$. aureus and P. aeruginosa. The completely quaternized forms of QA-PEI nanoparticles modified with 1-bromohexane and $\alpha$-bromotoluene had higher antibacterial activity than their partially quaternized counterparts. When 1-bromodecane was used, a reverse effect was observed (Figure 11). Fully quaternized QA-PEI, $N$-alkylated with 1-bromohexane, produced $70 \%$ and $86 \%$ lower MIC values against $S$. aureus and P. aeruginosa than their incompletely quaternized counterparts, respectively. A similar trend was observed for the QA-PEI $N$-alkylated with $\alpha$-bromotoluene. As the degree of quaternization increased, the MIC values decreased by $50 \%$ and $78 \%$, respectively. The MIC values that emerged with QA-PEI $N$-alkylated with 1-bromodecane, on the contrary, increased respectively by $119 \%$ and $252 \%$, due to complete quaternization. These results revealed the influence of bacteria class on the QA-PEI antibacterial efficiency. P. aeruginosa exhibited higher resistance to QA-PEI compared to S. aureus. Differences in the cell wall structure between Gram-positive and Gram-negative bacteria are responsible for this effect. Gram-positive bacteria, represented here by S. aureus, have a loosely packed polyglycane cell wall, which facilitates its deterioration due to the interaction with QA-PEI. Gram-negative bacteria, represented here by $P$. aeruginosa, have an additional membrane composed of a phospholipid bilayer, which acts as a barrier against QA-PEI $[65,66,105]$.

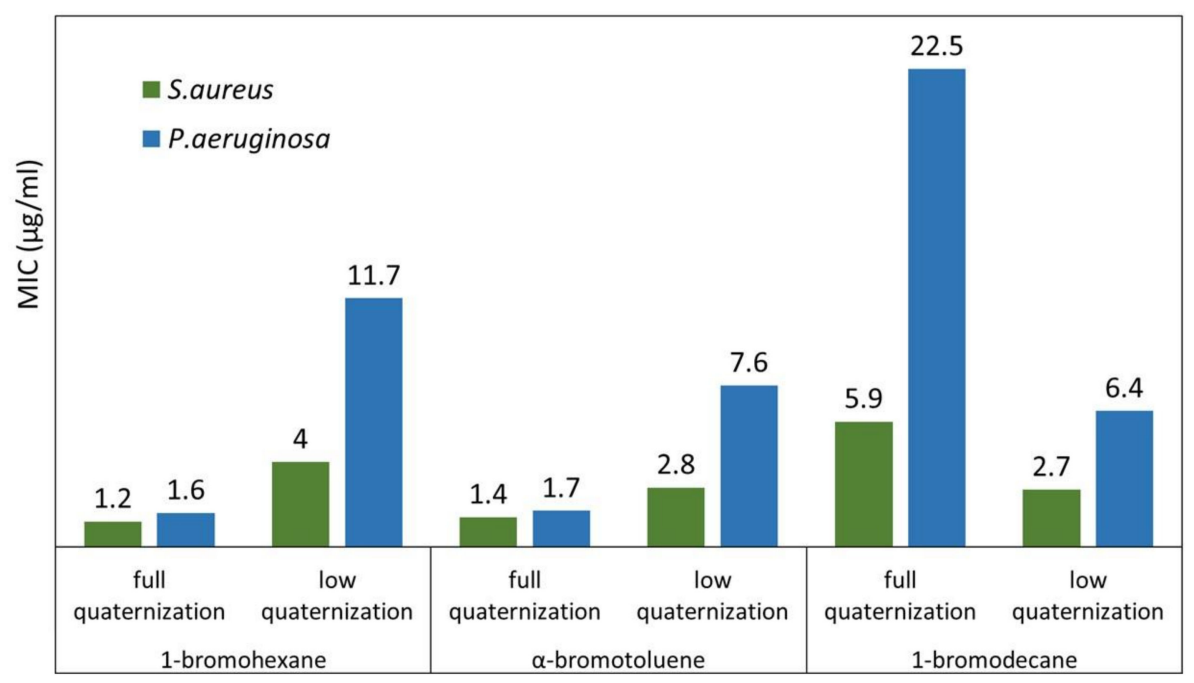

Figure 11. MIC $(\mu \mathrm{g} / \mathrm{mL})$ values measured for linear QA-PEI, distinguished by their quaternization degree and $N$-alkyl substituents, in tests against S. aureus and P. aeruginosa. Data from [86].

The influence of the quaternization degree on the antibacterial activity of linear QA-PEI was confirmed by Gao et al. [36] in tests against $E$. coli. Propylene oxide was used as the $N$-alkylation agent and benzyl chloride as the quaternization agent. The increase in the quaternization degree resulted in a decrease in the QA-PEI concentration required to kill the bacteria. They reported that QA-PEI with a quaternization degree of $54.9 \%$, at a concentration of $15 \mu \mathrm{g} / \mathrm{mL}$, killed almost all E. coli bacteria after four minutes, whereas QA-PEI with a quaternization degree of $40.8 \%$, at the same concentration, killed only about $80 \%$ of bacteria over the same time. 


\subsection{Effect of Counterion}

As mentioned before, QA-PEI derivatives inactivate bacteria by disrupting the cellular membrane due to electrostatic interaction with negatively charged bacteria and the replacement of $\mathrm{Ca}^{2+}$ and/or $\mathrm{Mg}^{2+}$ by biocidal cations. In this regard, the identity of the counter anion could play a role in the antimicrobial performance of polymeric quaternary ammonium salts. However, many studies on polymeric quaternary ammonium salts show that the counter anions, such as chloride, bromide, iodide, hydroxide, and phosphate, play a minor role in their biocidal performance [105]. No difference in the antimicrobial behavior is shown for QA-PEI nanoparticles.

The effect of the counterion type on the antibacterial activity of QA-PEI nanoparticles was demonstrated by Youdovin-Farber et al. [60], who partially replaced the original iodide anions with nitrate or acetate counterions. The antibacterial activity of the QA-PEI nanoparticles was then determined against $S$. aureus. The concentration of QA-PEI nanoparticles required to inhibit bacterial growth was $40 \mu \mathrm{g} / \mathrm{mL}$ for QA-PEI nanoparticles with nitrate and acetate anions and $80 \mu \mathrm{g} / \mathrm{mL}$ for QA-PEI nanoparticles with iodide counter anions. These results led to the conclusion that the anion type did not cause significant differences in the bacterial growth inhibition exhibited by QA-PEI nanoparticles, which was consistent with the results achieved in the study regarding linear QA-PEI derivatives.

\subsection{Relationship Between the $\mathrm{pH}$ and Antibacterial Properties of QA-PEI Nanoparticles}

In addition to the chemical structure, the $\mathrm{pH}$ can be recognized as a physical factor affecting the antibacterial properties of QA-PEI nanoparticles.

QA-PEI has minimal antibacterial activity at the $\mathrm{pH}$ value corresponding to the isoelectric point of the bacteria, which represents the $\mathrm{pH}$ where bacterial cell surfaces are not charged, thus disallowing the interaction between these surfaces and the positively-charged nanoparticles [36].

Dental materials operate in the oral cavity in a saliva environment. In the oral cavity, the $\mathrm{pH}$ is maintained near neutrality by saliva and ranges from 6.7 to 7.3 [106]. Therefore, it is important to study the antibacterial activity of QA-PEI nanoparticles at various $\mathrm{pH}$, in particular within the range mentioned above.

The relationship between the antibacterial activity of QA-PEI nanoparticles against salivary bacteria at various $\mathrm{pH}$ still requires testing. Gao et al. [36] tested this relationship for the linear QA-PEI against E. coli. The isoelectric point of the protein of E. coli cells was observed at $\mathrm{pH} 4.5$. QA-PEI emerged with negligible antibacterial efficiency at this $\mathrm{pH}$. As the $\mathrm{pH}$ increased above 4.5, the antibacterial activity of QA-PEI increased. The antibacterial activity maximum was observed at $\mathrm{pH}$ 6 and higher due to the strengthening of the electrostatic interactions between the positively-charged QA-PEI and the negatively-charged bacterial cell surfaces.

\subsection{Effect of Oxidizing Environment}

An interesting issue related to the antibacterial activity of QA-PEI nanoparticles is the influence of aggressive environments. Farah et al. [83] studied the effect of different oxidizing agents, including hydroxide peroxide, oxygen, and air, on the chemical stability of QA-PEI nanoparticles and their antibacterial activity against $E$. faecalis. The QA-PEI nanoparticles exhibited high chemical stability as no changes in the chemical structure or effective positive charge were observed after exposure for one week to different oxidizers. The antibacterial activity of aged QA-PEI nanoparticles was assessed by testing the antibacterial action of the commercial dental composite enriched with QA-PEI nanoparticles in the amounts of $0.5,1$, and $2 \mathrm{wt} . \%$. The exposure of QA-PEI nanoparticles to hydrogen peroxide for one week resulted in the highest antibacterial activity of modified composites and ultimately resulted in total bacterial growth inhibition at a QA-PEI nanoparticle concentration of $1 \mathrm{wt} . \%$. The total inhibition of bacterial growth for composites modified with the QA-PEI nanoparticles exposed to $\mathrm{O}_{2}$ for one week was achieved at a concentration of $2 \mathrm{wt} . \%$. The samples that were exposed to air induced total bacterial growth inhibition along with a QA-PEI nanoparticle concentration of $2 \mathrm{wt}$ \%; however, 
a longer aging period of 1 month was required. The increase in activity after one month in the latter case could be explained by surface changes in QA-PEI nanoparticles, which resulted in an increase in the number of active sites.

\section{Properties of Dental Composite Restorative Materials Modified with QA-PEI Nanoparticles}

Quaternary ammonium PEI derivatives, including QA-PEI nanoparticles, are recognized as compounds with selective cytotoxicity towards bacteria and fungi while remaining harmless to mammalian cells $[33,86,107,108]$. Therefore, QA-PEI nanoparticles, added at low concentrations, have the potential to be effective biocides for dental composite applications. So far, a series of commercial dental composite restorative materials have been modified by the physical admixing of 1 to $2 \mathrm{wt}$ \% QA-PEI nanoparticle powder and tested for antibacterial and physico-mechanical properties (Table 3). For determining the antimicrobial activity of dental materials modified with QA-PEI nanoparticles, Direct Contact Test (DCT), and the Agar Diffusion Test (ADT) are the most common methods. In addition, inhibition zone measurement is typically applied to detect the diffusion of biocide. The biological response is most often tested against $S$. mutans $[80,85,92,93]$, which is the main cause of secondary dental caries [109-111]. However, other bacteria strains are also tested in this work (Table 3). In addition to the microbiological tests, the modified dental materials are tested regarding the degree of conversion (DC) in the dimethacrylate composite matrix and their mechanical properties, such as flexural strength and flexural modulus.

Table 3. Commercially-available dental composite materials tested for antibacterial activity after modification with QA-PEI nanoparticles.

\begin{tabular}{|c|c|c|c|c|}
\hline $\begin{array}{c}\text { Dental Composite } \\
\text { Material/Manufacturer }\end{array}$ & Chemical Composition & $\begin{array}{c}\text { Content of } \\
\text { QA-PEI } \\
\text { Nanoparticles } \\
\text { (wt. \%) }\end{array}$ & Tested Bacteria & Ref. \\
\hline Filtek $^{\mathrm{TM}} \mathrm{Z} 250 / 3 \mathrm{M}^{\mathrm{TM}}$ & $\begin{array}{c}\text { Zirconia/silica filler, } \\
\text { Bis-GMA, UDMA, } \\
\text { Bis-EMA [112] }\end{array}$ & 1 & S. mutans & [80] \\
\hline Filtek Flow/3M ${ }^{\mathrm{TM}}$ & $\begin{array}{l}\text { Zirconia/silica filler, } \\
\text { Bis-GMA, TEGDMA }\end{array}$ & $\begin{array}{l}1 \\
1 \\
2 \\
1\end{array}$ & $\begin{array}{c}\text { S. mutans } \\
\text { S. aureus, S. epidermis, } \\
\text { E. faecalis, } \\
\text { P. aeruginosa, } \\
\text { E. coli } \\
\text { in vivo studies }\end{array}$ & $\begin{array}{l}{[80,85]} \\
{[90]} \\
{[91]}\end{array}$ \\
\hline Single Bond $/ 3 \mathrm{M}^{\mathrm{TM}}$ & $\begin{array}{c}\text { Dimethacrylate resins, } \\
\text { HEMA [113] }\end{array}$ & 1 & S. mutans & [80] \\
\hline $\begin{array}{l}\text { Q Core/BJM Laboratories } \\
\text { Ltd. }\end{array}$ & $\begin{array}{l}\text { Bis-GMA, TEGDMA, } \\
\text { aluminoborosilicate filler, } \\
\text { fluoride-releasing filler }\end{array}$ & 1 & $\begin{array}{l}\text { A. viscosus, } \\
\text { S. mutans }\end{array}$ & [92] \\
\hline $\begin{array}{c}\text { Filtek Supreme XT } \\
\text { Flowable } \\
\text { Restorative } / 3 \mathrm{M}^{\mathrm{TM}}\end{array}$ & $\begin{array}{c}\text { Zirconia/silica filler } \\
\text { Bis-GMA, TEGDMA, } \\
\text { Bis-EMA [114] }\end{array}$ & $\begin{array}{c}0.5 \\
1 \\
2\end{array}$ & E. faecalis & {$[83,88]$} \\
\hline $\begin{array}{l}\text { Filtek Supreme XTE } \\
\text { Flowable } \\
\text { Restorative/3M } 3 \mathrm{M}^{\mathrm{TM}}\end{array}$ & $\begin{array}{c}\text { Zirconia/silica filler, } \\
\text { fluoride filler, Bis-GMA, } \\
\text { TEGDMA, procrylat resins } \\
{[115]}\end{array}$ & $\begin{array}{l}1 \\
2\end{array}$ & $\begin{array}{l}\text { E. faecalis, S. mutans, } \\
\text { A. viscosus, L. casei }\end{array}$ & [93] \\
\hline
\end{tabular}

The antibacterial tests on the modifications of commercial dental composite materials with QA-PEI nanoparticles were carried out with QA-PEI nanoparticle content from 0.5 to $2.0 \mathrm{wt} . \%$. The presence of $1 \mathrm{wt} . \%$ QA-PEI nanoparticles mostly triggered satisfactory antibacterial activity.

After incorporation of $1 \mathrm{wt} . \%$ QA-PEI nanoparticles, Filtek Z250 $\left(3 \mathrm{M}^{\mathrm{TM}}\right)$ and Filtek Flow $\left(3 \mathrm{M}^{\mathrm{TM}}\right)$ achieved strong and long-lasting (over one month) surface antibacterial activity against S. mutans $[80,85,89]$. The inhibition zone was not observed, which indicates that QA-PEI nanoparticles 
were not eluted from the composite. The modification of the Filtek Flow composite with QA-PEI nanoparticles caused an increase in the hydrophobic character of its surface, which was manifested by an increase in the water contact angle [89]. Flexural tests on Filtek Z250 hybrid composite did not reveal any relevant effects for the modification with QA-PEI nanoparticles. The flexural strength of the Filtek Flow flowable composite was more sensitive to the addition of QA-PEI nanoparticles. Its value decreased by approximately $40 \%$ in comparison to the neat composite, whereas the modulus remained unaffected $[80,85]$.

Filtek Flow $\left(3 \mathrm{M}^{\mathrm{TM}}\right)$ enriched with 1 and 2 wt.\% QA-PEI nanoparticles also showed antibacterial activity against S. aureus, S. epidermis, E. faecalis, P. aeruginosa, and E. coli [90]. The complete growth inhibition of $S$. aureus and $E$. faecalis was achieved for the composite modification with $1 \mathrm{wt} . \%$ QA-PEI nanoparticles. The complete growth inhibition of S. epidermis, P. aeruginosa, and E. coli required a higher content of $2 \mathrm{wt} . \%$ QA-PEI nanoparticles. The addition of $1 \mathrm{wt} . \%$ QA-PEI nanoparticles only reduced the bacterial growth on the surface of these composites. Generally, this diversification of results coincided with the classification of bacterial species into Gram-positive and Gram-negative bacteria. Composites modified with Gram-negative bacteria, P. aeruginosa and E. coli, showed weaker biological responses than those modified with the Gram-positive bacteria S. aureus and E. faecalis. Exceptionally, S. epidermis, the Gram-positive strain, was more resistant to the biocidal action of QA-PEI nanoparticles than the other tested Gram-positive bacteria. These results supported the conclusion that the specific structure of the cell wall of the Gram-negative bacteria reduced the antibacterial efficiency of QA-PEI nanoparticles [65,66,99-101,105]. An inhibition zone was not observed around all the modified composites, which showed that leaching of QA-PEI nanoparticles did not take place.

The Filtek Supreme XT flowable restorative system $\left(3 \mathrm{M}^{\mathrm{TM}}\right)$ after modification with QA-PEI nanoparticles was tested for antibacterial activity against a series of Gram-positive bacteria: E. faecalis $[83,88,93]$, S. mutans, A. viscosus, L. casei, and whole saliva bacteria [93]. Satisfactory antibacterial activity was achieved for composites modified with $1 \mathrm{wt}$ \% QA-PEI nanoparticles.

The Filtek Supreme XT composite modified with $2 \mathrm{wt} . \%$ QA-PEI nanoparticles were subjected to further testing regarding the degree of conversion in the dimethacrylate matrix and antibacterial activity against $E$. faecalis relative to the distribution of nanoparticles throughout the sample mass [93]. $\mathrm{X}$-ray photoelectron spectroscopy revealed the presence of iodide cations on both the outer and inner surfaces of the modified composite. However, the concentration of nanoparticles was higher on the inner surface. Despite this fact, total bacterial growth inhibition was achieved for both tested surfaces. The degree of conversion (DC) in the dimethacrylate matrix was not negatively affected by the addition of $2 \mathrm{wt}$.\% QA-PEI nanoparticles. The difference between the DC values determined for unmodified versus modified composites was statistically insignificant and corresponded to around $51 \%$ and 53\%, respectively. The neutral effect of the modification of dental resin-based material with QA-PEI nanoparticles is particularly important for its proper functioning. It is well known that mechanical and physico-chemical properties of the methacrylate-based dental materials strongly depend on the DC. A decrease in the DC results in the mechanical weakening of the composite $[8,102]$.

Due to the modification with $1 \mathrm{wt} . \%$ QA-PEI nanoparticles, commercial dimethacrylate-based foundation material Q Core (BJM Laboratories) showed antibacterial activity against $A$. viscosus and S. mutans [92]. As both A. viscosus and S. mutans represented the Gram-positive bacterial strain, both bacteria revealed similar antibacterial efficiency. The quantity of bacteria accumulated on the surfaces of the materials modified with QA-PEI nanoparticles decreased by six orders of magnitude relative to unmodified materials.

The influence of polishing on the antibacterial activity of a commercial composite was also tested. Polishing is an integral part of dental filling procedure as it provides optimal aesthetics and marginal integrity of the restorative interface [116]. The test results on the antibacterial activity of the Q Core (BJM Laboratories) commercial dental composite enriched with $1 \mathrm{wt} . \%$ QA-PEI nanoparticles against A. viscosus and S. mutans did not reveal any negative effect of polishing on the biocidal efficiency of the modified material [92]. 


\section{QA-PEI Nanoparticles in Other Dental Materials}

Dental plaque accumulation and the formation of secondary caries can also be associated with the use of other types of dental materials, such as orthodontic cements, adhesives, and endodontic sealers. Thus, some studies investigated those types of materials after modification by incorporating QA-PEI nanoparticles in order to determine if such modifications could increase their antibacterial activity against oral bacteria (Table 4 ).

Table 4. Commercially-available dental materials tested for antibacterial activity after modification with QA-PEI nanoparticles.

\begin{tabular}{|c|c|c|c|c|}
\hline $\begin{array}{c}\text { Dental Composite } \\
\text { Material/Manufacturer }\end{array}$ & $\begin{array}{l}\text { Type of Dental } \\
\text { Material }\end{array}$ & $\begin{array}{c}\text { Content of } \\
\text { QA-PEI } \\
\text { Nanoparticles } \\
\text { (wt. \%) }\end{array}$ & Tested Bacteria & Ref. \\
\hline AH Plus/Dentsply DeTrey & $\begin{array}{l}\text { Root canal sealer } \\
\text { pastes }\end{array}$ & $\begin{array}{c}0.5 \\
1 \\
2\end{array}$ & E. faecalis & {$[88]$} \\
\hline AH 26/Dentsply DeTrey & $\begin{array}{l}\text { Root canal sealer } \\
\text { pastes }\end{array}$ & $\begin{array}{c}0.5 \\
1 \\
2\end{array}$ & E. faecalis & [88] \\
\hline BJM RCS/B.J.M. Laboratories & $\begin{array}{l}\text { Root canal sealer } \\
\text { pastes }\end{array}$ & $\begin{array}{c}0.5 \\
1 \\
2\end{array}$ & E. faecalis & [88] \\
\hline Single Bond adhesive $/ 3 \mathrm{M}^{\mathrm{TM}}$ & Bonding resin & 1 & S. mutans & [80] \\
\hline RelyX Temp NE/3M ESPE & Provisional cement & $\begin{array}{c}0.5 \\
1 \\
2\end{array}$ & $\begin{array}{l}\text { S. mutans } \\
\text { E. faecalis }\end{array}$ & [97] \\
\hline \multirow{3}{*}{ NeoBond } & \multirow{3}{*}{$\begin{array}{l}\text { Orthodontic } \\
\text { cement }\end{array}$} & $\begin{array}{c}1 \\
1.5\end{array}$ & S. mutans & [94] \\
\hline & & 1 & $\begin{array}{l}\text { S. mutans } \\
\text { L. casei }\end{array}$ & [117] \\
\hline & & 1 & S. mutans & [95] \\
\hline $\begin{array}{c}\text { Transbond Plus/3M Oral } \\
\text { Care }\end{array}$ & $\begin{array}{l}\text { Orthodontic } \\
\text { adhesive }\end{array}$ & 1 & S. mutans & [95] \\
\hline Transbond CT/3M Oral Care & $\begin{array}{l}\text { Orthodontic } \\
\text { adhesive }\end{array}$ & 1 & S. mutans & [95] \\
\hline GC Fuji ORTHO LC/GC & $\begin{array}{l}\text { Orthodontic } \\
\text { cement }\end{array}$ & 1 & S. mutans & [95] \\
\hline GC CX-Plus/SHOFU & $\begin{array}{l}\text { Orthodontic } \\
\text { cement }\end{array}$ & 1 & S. mutans & [95] \\
\hline $\begin{array}{c}\text { Simplex TM P Bone } \\
\text { Cement/Stryker MedEd }\end{array}$ & Bone cement & $\begin{array}{l}1 \\
2 \\
3\end{array}$ & $\begin{array}{l}\text { S. aureus } \\
\text { E. faecalis }\end{array}$ & [96] \\
\hline
\end{tabular}

Endodontic sealers are utilized for the obturation of root canals. Studies on their modification to achieve materials of biocidal activity are particularly important for modern dentistry. As the root canal constitutes the ultimate barrier between the oral cavity and inner body, it must be particularly protected against bacterial infections. The modification of the commercial epoxy-amine root canal sealer pastes, including AH Plus, AH26 (Dentsply DeTrey), and BJM RCS (B.J.M. Laboratories) with wt.1\% QA-PEI nanoparticles, resulted in total bacterial growth inhibition against E. faecalis [88].

Commercial dental cements and adhesives were also tested for modification with QA-PEI nanoparticles. They are used in orthodontics for securing brackets to the teeth and for luting artificial teeth in place. In recent years, there has been considerable growth in the use of adhesive systems to repair teeth damaged by caries [117-119]. 
The Single Bond ( $\left(3 \mathrm{M}^{\mathrm{TM}}\right)$ adhesive modified with $1 \mathrm{wt} . \%$ QA-PEI nanoparticles showed antibacterial activity against $S$. mutans [80]. Moreover, the inhibition zone was not observed around the sample.

The provisional commercial dental cement, RelyX Temp NE (3M ESPE), was another material that showed antibacterial activity against $S$. mutans and E. faecalis due to modification with $1 \mathrm{wt} . \%$ QA-PEI nanoparticles. No bacterial growth was observed on samples aged up to 14 days, which could be recognized as long-lasting antibacterial activity [97].

The modification of the NeoBond (Dentsply) orthodontic cement with 1.5 wt.\% QA-PEI nanoparticles resulted in the complete inhibition of $S$. mutans bacterial growth and did not change material biocompatibility [94]. Another study showed that the same orthodontic cement, enriched with $1 \mathrm{wt} . \%$ QA-PEI nanoparticles, reduced and inhibited the bacterial growth of S. mutans and L. casei in the oral biofilm adjacent to bonded brackets by approximately $90 \%$ [120]. Additionally, the bacterial biomass around orthodontic brackets was reduced by more than $40 \%$. Therefore, this method can be recognized as advantageous in preventing the development of caries adjacent to orthodontic bracket devices.

The study on the NeoBond (Dentsply) orthodontic adhesive revealed that the DC in the methacrylate matrix could decrease due to the addition of QA-PEI nanoparticles (Figure 12). The presence of $1 \mathrm{wt} . \%$ QA-PEI nanoparticles caused a 3\% decrease in the DC measured $10 \mathrm{~min}$ after irradiation, whereas the presence of $1.5 \mathrm{wt} . \%$ QA-PEI nanoparticles caused a $17.5 \%$ decrease in the $\mathrm{DC}$, relative to the neat material. The influence of the decrease in the DC on the material mechanical performance was tested by measuring the shear bond strength (SBS). The results did not show a negative effect on SBS.

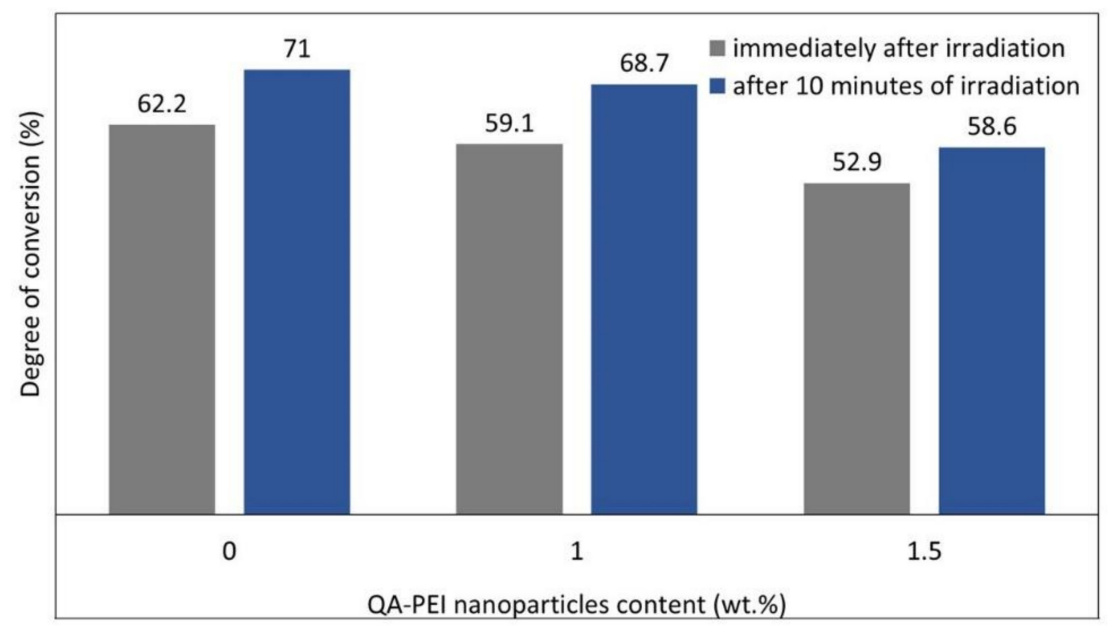

Figure 12. Degree of conversion of orthodontic adhesives modified with QA-PEI nanoparticles. Data from [94].

Orthodontic cements and adhesives modified with QA-PEI nanoparticles do not always show sufficient antibacterial activity. Among the studied orthodontic adhesives NeoBond (Dentsply), Transbond Plus (3M Oral Care), Transbond CT (3M Oral Care), and orthodontic cements GC Fuji ORTHO LC (GC), GC CX-Plus (SHOFU), only the NeoBond adhesive and GC Fuji ORTHO LC cement exhibited strong and long-lasting antibacterial activity against $S$. mutans due the modification with $1 \mathrm{wt} . \%$ QA-PEI nanoparticles. This effect was observed even after one month [95]. Modification of these two materials with the QA-PEI nanoparticles reduced the bacterial counts by about $95 \%$ and $97 \%$, respectively. No inhibition zone was observed around any of the tested samples.

Additionally, we would like to present the results for the modification of commercial bone cement with QA-PEI nanoparticles. Bone cements are based on poly(methyl methacrylate) (PMMA), which represents a linear polymer that is structurally different from the crosslinked dimethacrylate-based dental materials. Therefore, the results achieved for this type of biomaterial can be valuable for 
PMMA-based dental materials, such as artificial teeth, denture bases, dentures, obturators, orthodontic retainers, temporary or provisional crowns, and for the repair of dental prostheses [121]. Simplex TM P Bone Cement (Stryker MedEd), due to the incorporation of $2 \mathrm{wt. \%}$ QA-PEI nanoparticles showed antibacterial activity against $S$. aureus and E. faecalis [96]. The inhibition zone was not observed around the tested samples, so it could be concluded that no amount of antibacterial agent was leached from the bone cement structure. Young's modulus of the modified materials was determined in order to evaluate the influence of QA-PEI nanoparticles on the mechanical properties of the cement. The Young's modulus values decreased from 2.31 GPa for the neat cement to $1.9 \mathrm{GPa}$ for the cement enriched with 2 wt.\% QA-PEI nanoparticles. However, the difference between those values was found to be statistically insignificant. The modulus of the material containing $3 \mathrm{wt} . \%$ QA-PEI nanoparticles was $1.8 \mathrm{GPa}$, which was significantly statistically lower than the modulus value of the unmodified material.

\section{Biocompatibility of Dental Materials Modified with QA-PEI Nanoparticles}

Certain commercial dental materials modified with QA-PEI nanoparticles were tested for biocompatibility and were subjected to initial in vivo testing.

Generally, dental materials in their cured form are non-toxic. However, they can reveal certain toxic effects to the human body due to leaching, which usually results from the presence of unreacted monomers and low molecular weight products of the chemical degradation of the dimethacrylate polymer network [102]. In the case of dental materials modified with QA-PEI nanoparticles, cytotoxicity could result from the presence of QA-PEI nanoparticles and/or their leaching [102]

The cytotoxicity of the QA-PEI modified dental materials was tested using macrophages and fibroblast cell lines and studying its effect on the secretion of tumor necrosis factor alpha (TNF $\alpha$ ) from the macrophages.

The addition of 1 wt.\% QA-PEI nanoparticles into commercial dental materials did not negatively affect their biocompatibility [89-91,98]. This effect was demonstrated on two commercial dental restorative composites, Filtek Z250, and Filtek Flow [89-91], as well as three commercial endodontic sealers, AH Plus (Dentsply Maillefer), Epiphany SE (Pentron Clinical Technologies), and GuttaFlow (Coltene/Whaledent) [98]. The cell viability was observed for each of the tested materials on both cell lines.

The increase in the amount of QA-PEI nanoparticles of up to $2 \mathrm{wt} . \%$ led to the diversification of results.

The dental restorative composites Filtek Z250 and Filtek Flow, modified with 2 wt.\% QA-PEI nanoparticles, did not reveal an increase in the material cytotoxicity. The cytotoxic effect was comparable with that of the native composite [89-91]. On that basis, it can be concluded that the addition of a maximum $2 \mathrm{wt} . \%$ QA-PEI nanoparticles does not alter the cytotoxicity of restorative dental composite materials. Moreover, it can be concluded that the dimethacrylate component (composite matrix) is the main source of cytotoxic effects in dental composite materials containing QA-PEI nanoparticles.

On the other hand, the incorporation of $2 \mathrm{wt}$.\% QA-PEI nanoparticles into tested endodontic sealers was recognized as slightly toxic [98]. Although the cell viability was observed for each of the tested sealers on both cell lines, the reduction in the TNF $\alpha$ secretion was observed for the modified AH Plus sealer. The modified Epiphany sealer reduced the TNF $\alpha$ secretion to an undetectable level, whereas the modification of GuttaFlow did not affect the TNF $\alpha$ secretion (in comparison to the unmodified sealers). This diversification of results is a very important outcome for the future design of dental materials modified with QA-PEI nanoparticles. The maximum content of QA-PEI in a dental material may vary depending on the intended use of the material, but also on the manufacturer and particular product.

The results for the modification of endodontic sealers with QA-PEI nanoparticles are particularly interesting. As commercial endodontic sealers usually contain substances recognized as cytotoxic, such as eugenol, paraformaldehyde, or polyketone [122], their replacement with QA-PEI nanoparticles seems to be an interesting alternative. 
Initial in vivo studies on the QA-PEI-modified dental material were also performed on the Filtek Flow restorative composite. The implantation of the modified restorative, containing up to $2 \mathrm{wt} . \%$ QA-PEI nanoparticles, into rat tissue indicated that an inflammatory reaction [89].

Satisfactory results were also achieved for another in vivo test for the Filtek Flow composite modified with $1 \mathrm{wt.} \%$ QA-PEI nanoparticles [91]. The modified and non-modified materials were inserted into a removable acrylic appliance. The device was worn by 10 volunteers for four hours to allow the build-up of intraoral biofilms. Then, the specimens were tested for bacterial vitality and biofilm thickness. The results indicated that composites containing QA-PEI nanoparticles exhibited antibacterial activity against salivary bacteria and were safe for oral use because no inflammation nor allergic reactions were sustained. The vitality rate in the QA-PEI nanoparticle-modified composites was reduced by more than $50 \%$, whereas biofilm thickness increased. The thicker biofilm that accumulated on the surfaces of composites containing QA-PEI nanoparticles primarily consisted of nonviable cells, whereas the thinner biofilm that was detected on the surfaces of control samples consisted mainly of viable cells. The in vitro tests showed a $70 \%$ decrease in viable bacteria due to the modification of the dental composites with QA-PEI nanoparticles.

\section{Conclusions and Future Perspectives}

The lack of antibacterial properties of commonly-used dental composite materials is the main problem associated with providing restoration longevity and avoiding surrounding tissue irritation. Dental materials can be enriched with various organic and inorganic biocides in order to give them microbiological activity. Many of them are known to have adverse effects on surrounding tissues or on human health in broad terms. Therefore, their leachates trigger a toxic response. QA-PEI nanoparticles represent an interesting alternative. Due to their polycationic character, resulting from the ammonium group in the repeating units, they exhibit strong and long-lasting antibacterial activity. Their nanoparticulate form allows application in small amounts; therefore, their distribution within a dental composite does not deteriorate the material's overall physico-chemical and mechanical properties. Additionally, these nanoparticles offer a wide range of potential chemical modifications, which results in a specific antibacterial activity. Since they do not increase the cytotoxicity of the modified dental materials, they can be recognized as being safe for mammalian cells.

This review shows that the structure of QA-PEI nanoparticles has to be carefully designed to achieve optimum antibacterial activity. It depends on the particular elements of the chemical structure and bacterial strain and may be summarized as follows: (i) polycationic character provides higher antibacterial activity if compared to monocationic compounds, (ii) both the excessive core stiffness and elasticity decreases antibacterial efficiency, (iii) the optimum dibromopentane crosslinker concentration is around $0.04 \mathrm{~mol} / \mathrm{mol} \mathrm{PEI}$ unit, (iv) $\mathrm{N}$-octyl is the optimum $\mathrm{N}$-alkyl substituent, (v) the optimum $\mathrm{N}$-alkylation ratio is 1 mole/PEI unit, (vi) the quaternization should be full, (vii) the antibacterial activity against Gram-positive bacteria is stronger than that against Gram-negative bacteria, (viii) many bacterial strains show QA-PEI antimicrobial susceptibility, (ix) when added in $1 \mathrm{wt} . \%$ into the commercial dental material, satisfactory antibacterial action is usually achieved.

Further systematic studies on the QA-PEI structure-bioactivity relationships are of great interest. They can lead to the development of materials presenting an optimal balance between antimicrobial activity and cytotoxicity. Moreover, extending research to other microorganisms can bring new potential applications. The examination of antiviral properties is particularly interesting from the perspective of the SARS-CoV-2 (COVID-19) pandemic.

The modification of dental materials with QA-PEI nanoparticles brings the following outcomes: (i) they are physically admixed, which represents the cheapest and easiest method of material physico-chemical modification; (ii) good antibacterial activity is achieved at $1 \mathrm{wt} . \%$ content; (iii) this content does not cause an increase in the original material cytotoxicity; (iv) $2 \mathrm{wt} . \%$ content causes a slight increase in the material cytotoxicity; (v) $1 \mathrm{wt} . \%$ content does not display harmful effects on living tissues; (vi) the nanoparticulate crosslinked form provides non-leaching properties; (vii) their 
presence does not decrease the degree of conversion in the composite; (viii) their presence does not cause deterioration in its flexural properties.

In view of the above, it can be concluded that the modification of dental materials with QA-PEI nanoparticles presents a viable alternative to currently used dental biocides. Nevertheless, QA-PEI modified materials have not yet been fully characterized and require further investigation. In particular, the following properties need to be examined: (i) mechanical behavior under tensile and compressive loading; (ii) other mechanical properties, such as hardness and abrasion resistance; (iii) glass temperature; (iv) water sorption; (v) polymerization shrinkage; (vi) degradation effects caused by the exposure to UV, $\mathrm{pH}$ (in respect to particular bacterium strains), and water (via Hofmann elimination); (vii) the biological and physical effects of long-lasting leaching. As the biocompatibility has only been initially assessed, it also requires further examination and in vitro as well as in vivo tests.

Although QA-PEI nanoparticles were originally designed to provide dental materials with antibacterial activity against oral bacteria, they may also prove to be suitable for other biomedical applications. Therefore, further studies on the modifications of other composite biomaterials with QA-PEI nanoparticles are highly desirable.

Author Contributions: Data curation, original draft preparation, editing, visualization, funding acquisition, M.C.; writing revisions, supervision, project administration, I.B.-R. and M.C.; conceptualization, resources, I.B.-R. All authors have read and agreed to the published version of the manuscript.

Funding: This research was funded by the Polish Budget Funds for Scientific Research in 2020 as core funding for research and development activities in the Silesian University of Technology-funding for young scientists, grant number 04/040/BKM20/0128.

Conflicts of Interest: The authors declare no conflict of interest. The funders had no role in the design of the study, the collection, analysis, or interpretation of data, the writing of the manuscript, or the decision to publish the results.

\section{References}

1. Watts, D.C. Dental Restorative Materials. In Materials Science and Technology: A Comprehensive Treatment; Cahn, R.W., Haasen, P., Kramer, E.J., Eds.; VCH: New York, NY, USA, 1992; Volume 14, pp. $209-258$.

2. Dursun, E.; Fron-Chabouis, H.; Attal, J.P.; Raskin, A. Bisphenol A Release: Survey of the Composition of Dental Composite Resins. Open Dent. J. 2016, 10, 446-453. [CrossRef] [PubMed]

3. Beyth, N.; Domb, A.J.; Weiss, E.I. An in Vitro Quantitative Antibacterial Analysis of Amalgam and Composite Resins. J. Dent. 2007, 35, 201-206. [CrossRef]

4. Padovani, G.C.; Fùcio, S.B.P.; Ambrosano, G.M.B.; Correr-Sobrinho, L.; Puppin-Rontani, R.M. In Situ Bacterial Accumulation on Dental Restorative Materials. CLSM/COMSTAT Analysis. Am. J. Dent. 2015, 28, 3-8.

5. Ali, S.; Sangi, L.; Kumar, N.; Khurshid, Z.; Zafar, M.S. Evaluating antibacterial and surface mechanical properties of chitosan modified dental resin composites. Technol. Health. Care. 2020, 28, 165-173. [CrossRef] [PubMed]

6. Kleverlaan, C.J.; Feilzer, A.J. Polymerization Shrinkage and Contraction Stress of Dental Resin Composites. Dent. Mater. 2005, 21, 1150-1157. [CrossRef]

7. El-Banna, A.; Sherief, D.; Fawzy, A.S. Resin-Based Dental Composites for Tooth Filling In Advanced Dental Biomaterials; Elsevier: Amsterdam, The Netherlands, 2019; pp. 127-173. [CrossRef]

8. Lin, G.S.S.; Abdul Ghani, N.R.N.; Ismail, N.H.; Singbal, K.P.; Yusuff, N.M.M. Polymerization Shrinkage and Degree of Conversion of New Zirconia-Reinforced Rice Husk Nanohybrid Composite. Eur. J. Dent. 2020, 14, 448-455. [CrossRef] [PubMed]

9. Chisini, L.A.; Collares, K.; Cademartori, M.G.; de Oliveira, L.J.C.; Conde, M.C.M.; Demarco, F.F.; Corrêa, M.B. Restorations in Primary Teeth: A Systematic Review on Survival and Reasons for Failures. Int. J. Paediatr. Dent. 2018, 28, 123-139. [CrossRef] [PubMed]

10. Bernardo, M.; Luis, H.; Martin, M.D.; Leroux, B.G.; Rue, T.; Leitão, J.; DeRouen, T.A. Survival and Reasons for Failure of Amalgam Versus Composite Posterior Restorations Placed in a Randomized Clinical Trial. J. Am. Dent. Assoc. 2007, 138, 775-783. [CrossRef] 
11. Ferrando-Magraner, E.; Bellot-Arcís, C.; Paredes-Gallardo, V.; Almerich-Silla, J.M.; García-Sanz, V.; Fernández-Alonso, M.; Montiel-Company, J.M. Antibacterial Properties of Nanoparticles in Dental Restorative Materials. A Systematic Review and Meta-Analysis. Medicina 2020, 56, 55. [CrossRef]

12. Wang, Y.; Hua, H.; Li, W.; Wang, R.; Jiang, X.; Zhu, M. Strong antibacterial dental resin composites containing cellulose nanocrystal/zinc oxide nanohybrids. J. Dent. 2019, 80, 23-29. [CrossRef]

13. Dias, H.B.; Bernardi, M.I.B.; Bauab, T.M.; Hernandes, A.C.; de Souza Rastelli, A.N. Titanium dioxide and modified titanium dioxide by silver nanoparticles as an antibiofilm filler content for composite resins. Dent. Mater. 2019, 35, e36-e46. [CrossRef] [PubMed]

14. Florez, F.L.E.; Hiers, R.D.; Larson, P.; Johnson, M.; O’Rear, E.; Rondinone, A.J.; Khajotia, S.S. Antibacterial dental adhesive resins containing nitrogen-doped titanium dioxide nanoparticles. Mater. Sci. Eng. C 2018, 93, 931-943. [CrossRef]

15. Zhou, W.; Peng, X.; Zhou, X.; Weir, M.D.; Melo, M.A.S.; Tay, F.R.; Imazato, S.; Oates, T.W.; Cheng, L.; $\mathrm{Xu}, \mathrm{H} . K . K$. In vitro evaluation of composite containing DMAHDM and calcium phosphate nanoparticles on recurrent caries inhibition at bovine enamel-restoration margins. Dent. Mater. 2020, 36, 1343-1355. [CrossRef]

16. Li, Y.; Hu, X.; Ruan, J.; Arola, D.; Ji, C.; Weir, M.; Oates, T.; Chang, X.; Zhang, K.; Xu, H. Bonding durability, antibacterial activity and biofilm $\mathrm{pH}$ of novel adhesive containing antibacterial monomer and nanoparticles of amorphous calcium phosphate. J. Dent. 2019, 81, 91-101. [CrossRef]

17. Khurshid, Z.; Zafar, M.; Qasim, S.; Shahab, S.; Naseem, M.; AbuReqaiba, A. Advances in Nanotechnology for Restorative Dentistry. Materials 2015, 8,717-731. [CrossRef] [PubMed]

18. Zafar, M.S.; Alnazzawi, A.A.; Alrahabi, M.; Fareed, M.A.; Najeeb, S.; Khurshid, Z. Nanotechnology and Nanomaterials in Dentistry In Advanced Dental Biomaterials; Elsevier: Amsterdam, The Netherlands, 2019; pp. 477-505. [CrossRef]

19. Bapat, R.A.; Chaubal, T.V.; Dharmadhikari, S.; Abdulla, A.M.; Bapat, P.; Alexander, A.; Dubey, S.K.; Kesharwani, P. Recent advances of gold nanoparticles as biomaterial in Dentistry. Int. J. Pharm. 2020, 583, 119596. [CrossRef] [PubMed]

20. Russo, T.; Gloria, A.; De Santis, R.; D’Amora, U.; Balato, G.; Vollaro, A.; Oliviero, O.; Improta, G.; Triassi, M.; Ambrosio, L. Preliminary Focus on the Mechanical and Antibacterial Activity of a PMMA-Based Bone Cement Loaded with Gold Nanoparticles. Bioact. Mater. 2017, 2, 156-161. [CrossRef]

21. Lee, S.J.; Heo, M.; Lee, D.; Han, S.; Moon, J.H.; Lim, H.N.; Kwon, I.K. Preparation and characterization of antibacterial orthodontic resin containing silver nanoparticles. Appl. Surf. Sci. 2018, 432, 317-323. [CrossRef]

22. Dutra-Correa, M.; Leite, A.A.B.V.; de Cara, S.P.H.M.; Diniz, I.M.A.; Marques, M.M.; Suffredini, I.B.; Fernandes, M.S.; Toma, S.H.; Araki, K.; Medeiros, I.S. Antibacterial effects and cytotoxicity of an adhesive containing low concentration of silver nanoparticles. J. Dent. 2018, 77, 66-71. [CrossRef]

23. Zhang, R.; Jones, M.M.; Moussa, H.; Keskar, M.; Huo, N.; Zhang, Z.; Visser, M.B.; Sabatini, C.; Swihart, M.T.; Cheng, C. Polymer-Antibiotic Conjugates as Antibacterial Additives in Dental Resins. Biomater. Sci. 2018, 7, 287-295. [CrossRef]

24. Boaro, L.C.C.; Campos, L.M.; Varca, G.H.C.; Dos Santos, T.M.R.; Marques, P.A.; Sugii, M.M.; Saldanha, N.R.; Cogo-Müller, K.; Brandt, W.C.; Braga, R.R.; et al. Antibacterial resin-based composite containing chlorhexidine for dental applications. Dent. Mater. 2019, 35, 909-918. [CrossRef]

25. Gilbert, P.; Moore, L.E. Cationic antiseptics: Diversity of action under a common epithet. J. Appl. Microbiol. 2005, 99, 703-715. [CrossRef]

26. Hora, P.I.; Pati, S.G.; McNamara, P.J.; Arnold, W.A. Increased Use of Quaternary Ammonium Compounds during the SARS-CoV-2 Pandemic and Beyond: Consideration of Environmental Implications. Environ. Sci. Technol. Lett. 2020, 7, 622-631. [CrossRef]

27. Liang, J.; Li, M.; Ren, B.; Wu, T.; Xu, H.H.K.; Liu, Y.; Peng, X.; Yang, G.; Weir, M.; Zhang, S.; et al. The anti-caries effects of dental adhesive resin influenced by the position of functional groups in quaternary ammonium monomers. Dent. Mater. 2018, 34, 400-411. [CrossRef]

28. Ballhaddad, A.A.; Ibrahim, M.S.; Weir, M.D.; Xu, H.H.K.; Melo, M.A.S. Concentration dependence of quaternary ammonium monomer on the design of high-performance bioactive composite for root caries restorations. Dent. Mater. 2020, 36, 266-278. [CrossRef] [PubMed] 
29. Maia, A.C.; Mangabeira, A.; Vieira, R.; Neves, A.; Lopes, R.T.; Pires, T.M.; Viana, G.; Cabral, L.; Cavalcante, L.; Portela, M.B. Experimental composites containing quaternary ammonium methacrylates reduce demineralization at enamel-restoration margins after cariogenic challenge. Dent. Mater. 2019, 35, e175-e183. [CrossRef]

30. Payne, M.E.; Lou, Y.; Zhang, X.; Sahiner, N.; Sandoval, N.R.; Shantz, D.F.; Grayson, S.M. Comparison of Cross-Linked Branched and Linear Poly(ethylene imine) Microgel Microstructures and Their Impact in Antimicrobial Behavior, Copper Chelation, and Carbon Dioxide Capture. ACS Appl. Polym. Mater. 2020, 2, 826-836. [CrossRef]

31. Shen, C.; Li, J.; Zhang, Y.; Li, Y.; Shen, G.; Zhu, J.; Tao, J. Polyethylenimine-Based Micro/Nanoparticles as Vaccine Adjuvants. Int. J. Nanomed. 2017, 12, 5443-5460. [CrossRef] [PubMed]

32. Lungu, C.N.; Diudea, M.V.; Putz, M.V.; Grudziński, I.P. Linear and Branched PEIs (Polyethylenimines) and Their Property Space. Int. J. Mol. Sci. 2016, 17, 555. [CrossRef]

33. Chen, Z.; Lv, Z.; Sun, Y.; Chi, Z.; Qing, G. Recent advancements in polyethyleneimine-based materials and their biomedical, biotechnology, and biomaterial applications. J. Mater. Chem. B 2020, 8, 2951-2973. [CrossRef]

34. Song, J.; Wang, D.; Wang, J.; Shen, Q.; Xie, C.; Lu, W.; Wang, R.; Liu, M. Low molecular weight polyethyleneimine modified by 2-aminoimidazole achieving excellent gene transfection efficiency. Eur. Polym. 2020, 140, 110017. [CrossRef]

35. Firoozi, B.; Nasser, Z.; Sofalian, O.; Sheikhzade-Mosadegh, P. Enhancement of the transfection efficiency of DNA into Crocus sativus L. cells via PEI nanoparticles. J. Integr. Agric. 2018, 17, 1768-1778. [CrossRef]

36. Garg, C.; Sharma, A.K.; Gupta, A.; Kumar, P. Anisamido-Polyethylenimines as Efficient Nonviral Vectors for the Transport of Plasmid DNA to Sigma Receptor-Bearing Cells In Vitro. J. Pharm. Sci. 2019, 108, 1552-1558. [CrossRef] [PubMed]

37. Gao, B.; Zhang, X.; Zhu, Y. Studies on the Preparation and Antibacterial Properties of Quaternized Polyethyleneimine. J. Biomater. Sci. Polym. Ed. 2007, 18, 531-544. [CrossRef] [PubMed]

38. Vakurov, A.; Simpson, C.E.; Daly, C.L.; Gibson, T.D.; Millner, P.A. Acetylcholinesterase-Based Biosensor Electrodes for Organophosphate Pesticide Detection. I. Modification of Carbon Surface for Immobilization of Acetylcholinesterase. Biosens. Bioelectron. 2004, 20, 1118-1125. [CrossRef] [PubMed]

39. Pessela, B.C.C.; Fernández-Lafuente, R.; Fuentes, M.; Vián, A.; García, J.L.; Carrascosa, A.V.; Mateo, C.; Guisán, J.M. Reversible Immobilization of a Thermophilic $\beta$-Galactosidase via Ionic Adsorption on PEI-Coated Sepabeads. Enzyme Microb. Tech. 2003, 32, 369-374. [CrossRef]

40. De Rosa, G.; Bochot, A.; Quaglia, F.; Besnard, M.; Fattal, E. A New Delivery System for Antisense Therapy: PLGA Microspheres Encapsulating Oligonucleotide/Polyethyleneimine Solid Complexes. Int. J. Pharm. 2003, 254, 89-93. [CrossRef]

41. Zhang, Y.; Tan, X.; Ren, T.; Jia, C.; Yang, Z.; Sun, H. Folate-modified carboxymethyl-chitosan/polyethylenimine/ bovine serum albumin based complexes for tumor site-specific drug delivery. Carbohydr. Polym. 2018, 198, 76-85. [CrossRef]

42. Liang, L.; Chen, Y.; Chen, X.M.; Zhang, Y.; Liu, Y. Cyclodextrin/polyethylenimine-based supramolecular nanoparticles for loading and sustained release of ATP. Chin. Chem. Lett. 2018, 29, 989-991. [CrossRef]

43. Liang, X.; Fan, X.; Li, R.; Li, S.; Shen, S.; Hu, D. Efficient removal of Cr(VI) from water by quaternized chitin/branched polyethylenimine biosorbent with hierarchical pore structure. Bioresour. Technol. 2018, 250, 178-184. [CrossRef]

44. Wang, M.; Yang, Q.; Zhao, X.; Wang, Z. Highly Efficient Removal of Copper Ions from Water by Using a Novel Alginate-Polyethyleneimine Hybrid Aerogel. Int. J. Biol. Macromol. 2019, 138, 1079-1086. [CrossRef]

45. Arshad, F.; Selvaraj, M.; Zain, J.; Banat, F.; Haija, M.A. Polyethylenimine modified graphene oxide hydrogel composite as an efficient adsorbent for heavy metal ions. Sep. Purif. Technol. 2019, 209, 870-880. [CrossRef]

46. Gao, J.; Wang, K.Y.; Chung, T.S. Design of Nanofiltration (NF) Hollow Fiber Membranes Made from Functionalized Bore Fluids Containing Polyethyleneimine (PEI) for Heavy Metal Removal. J. Membr. Sci. 2020, 603, 118022. [CrossRef]

47. Godiya, C.B.; Sayed, S.M.; Xiao, Y.; Lu, X. Highly Porous Egg White/Polyethyleneimine Hydrogel for Rapid Removal of Heavy Metal Ions and Catalysis in Wastewater. React. Funct. Polym. 2020, 149, 104509. [CrossRef] 
48. Zhang, Z.; Chen, H.; Wu, W.; Pang, W.; Yan, G. Efficient Removal of Alizarin Red S from Aqueous Solution by Polyethyleneimine Functionalized Magnetic Carbon Nanotubes. Bioresour. Technol. 2019, 293, 122100. [CrossRef] [PubMed]

49. Quan, X.; Sun, Z.; Meng, H.; Han, Y.; Wu, J.; Xu, J.; Xu, Y.; Zhang, X. Polyethyleneimine (PEI) Incorporated Cu-BTC Composites: Extended Applications in Ultra-High Efficient Removal of Congo Red. J. Solid State Chem. 2019, 270, 231-241. [CrossRef]

50. Bektar, M.; Ali Rasekh, H.; Jaafar Soltanianfard, M. Synthesis and Characterization of CoFe2O4@SiO2-Polyethyleneimine Magnetic Nanoparticle and Its Application for Ultrasonic-Assisted Removal of Disulfine Blue Dye from Aqueous Solution. Arab. J. Chem. 2020, 13, 5430-5437. [CrossRef]

51. Li, X.; Wang, Z.; Ning, J.; Gao, M.; Jiang, W.; Zhou, Z.; Li, G. Preparation and Characterization of a Novel Polyethyleneimine Cation-Modified Persimmon Tannin Bioadsorbent for Anionic Dye Adsorption. J. Environ. Manag. 2018, 217, 305-314. [CrossRef]

52. Xiao, Y.; Huang, W.; Xu, K.; Li, M.; Fan, M.; Wang, K. Preparation of Anion Exchange Membrane with Branch Polyethyleneimine as Main Skeleton Component. Mater. Des. 2018, 160, 698-707. [CrossRef]

53. Jiang, W.; Lin, L.; Xu, X.; Wang, H.; Xu, P. Physicochemical and Electrochemical Characterization of Cation-Exchange Membranes Modified with Polyethyleneimine for Elucidating Enhanced Monovalent Permselectivity of Electrodialysis. J. Membr. Sci. 2019, 572, 545-556. [CrossRef]

54. Pan, J.; Ding, J.; Tan, R.; Chen, G.; Zhao, Y.; Gao, C.; van der Bruggen, B.; Shen, J. Preparation of a Monovalent Selective Anion Exchange Membrane through Constructing a Covalently Crosslinked Interface by Electro-Deposition of Polyethyleneimine. J. Membr. Sci. 2017, 539, 263-272. [CrossRef]

55. Yang, Z.; Li, Z.; Zhang, F.; Yang, B.; Zhang, S. A novel hydrophilic polymer-based anion exchanger grafted by quaternized polyethyleneimine for ion chromatography. Talanta 2019, 197, 199-203. [CrossRef] [PubMed]

56. Keller, L.; Ohs, B.; Lenhart, J.; Abduly, L.; Blanke, P.; Wessling, M. High capacity polyethylenimine impregnated microtubes made of carbon nanotubes for $\mathrm{CO}_{2}$ capture. Carbon 2018, 126, 338-345. [CrossRef]

57. Zhang, H.; Goeppert, A.; Kar, S.; Prakash, G.K.S. Structural parameters to consider in selecting silica supports for polyethylenimine based $\mathrm{CO}_{2}$ solid adsorbents. Importance of pore size. J. CO2 Util. 2018, 26, 246-253. [CrossRef]

58. Chen, Q.; Wang, S.; Rout, K.R.; Chen, D. Development of polyethylenimine (PEI)-impregnated mesoporous carbon spheres for low-concentration $\mathrm{CO}_{2}$ capture. Catal. Today. 2020. [CrossRef]

59. Jung, W.; Park, J.; Won, W.; Lee, K.S. Simulated moving bed adsorption process based on a polyethylenimine-silica sorbent for $\mathrm{CO}_{2}$ capture with sensible heat recovery. Energy 2018, 150, 950-964. [CrossRef]

60. Ira, Y.F.; Golenser, J.; Nurit, B.; Weiss, E.; Domb, A. Quaternary Ammonium Polyethyleneimine: Antibacterial Activity. J. Nanomater. 2010, 826343. [CrossRef]

61. Gibney, K.A.; Sovadinova, I.; Lopez, A.I.; Urban, M.; Ridgway, Z.; Caputo, G.A.; Kuroda, K. Poly(Ethylene Imine)s as Antimicrobial Agents with Selective Activity. Macromol. Biosci. 2012, 12, 1279-1289. [CrossRef]

62. Gerba, C.P. Quaternary ammonium biocides: Efficacy in application. Appl. Environ. Microbiol. 2015, 81, 464-469. [CrossRef]

63. Tuladhar, E.; de Koning, M.C.; Fundeanu, I.; Beumer, R.; Duizer, E. Different Virucidal Activities of Hyperbranched Quaternary Ammonium Coatings on Poliovirus and Influenza Virus. Appl. Environ. Microbiol. 2012, 78, 2456-2458. [CrossRef]

64. United States Environmental Protection Agency. List N: Disinfectants for Use against SARS-CoV-2. Available online: https://www.epa.gov/pesticide-registration/list-n-disinfectants-use-against-sars-cov-2 (accessed on 23 June 2020).

65. Anselme, K.; Davidson, P.; Popa, A.M.; Giazzon, M.; Liley, M.; Ploux, L. The interaction of cells and bacteria with surfaces structured at the nanometre scale. Acta Biomater. 2010, 6, 3824-3846. [CrossRef] [PubMed]

66. Uday, S.P.; Thiyagarajan, D.; Goswami, S.; Adhikari, M.D.; Das, G.; Ramesh, A. Amphiphile-mediated enhanced antibiotic efficacy and development of a payload nanocarrier for effective killing of pathogenic bacteria. J. Mater. Chem. B 2014, 2, 5818-5827. [CrossRef]

67. Gottenbos, B.; Grijpma, D.W.; van der Mei, H.C.; Feijen, J.; Busscher, H.J. Antimicrobial Effects of Positively Charged Surfaces on Adhering Gram-Positive and Gram-Negative Bacteria. J. Antimicrob. Chemother. 2001, 48, 7-13. [CrossRef] 
68. Brown, S.; Santa Maria, J.P.; Walker, S. Wall Teichoic Acids of Gram-Positive Bacteria. Annu. Rev. Microbiol. 2013, 67, 313-336. [CrossRef] [PubMed]

69. Swoboda, J.G.; Campbell, J.; Meredith, T.C.; Walker, S. Wall Teichoic Acid Function, Biosynthesis, and Inhibition. Chembiochem 2010, 11, 35-45. [CrossRef]

70. Beveridge, T.J. Structures of Gram-Negative Cell Walls and Their Derived Membrane Vesicles. J. Bacteriol. 1999, 181, 4725-4733. [CrossRef]

71. Zhang, G.; Meredith, T.C.; Kahne, D. On the Essentiality of Lipopolysaccharide to Gram-Negative Bacteria. Curr. Opin. Microbiol. 2013, 16, 779-785. [CrossRef]

72. Tashiro, T. Antibacterial and Bacterium Adsorbing Macromolecules. Macromol. Mater. Eng. 2001, $286,63-87$. [CrossRef]

73. Ge, Y.; Wang, S.; Zhou, X.; Wang, H.; Xu, H.H.K.; Cheng, L. The Use of Quaternary Ammonium to Combat Dental Caries. Materials 2015, 8, 3532-3549. [CrossRef] [PubMed]

74. Arora, A.; Mishra, A. Antibacterial Polymers-A Mini Review. Mater. Today Proc. 2018, 5, $17156-17161$. [CrossRef]

75. Iftekhar, H. Nanocomposite restorative materials for dental caries management. In Applications of Nanocomposite Materials in Dentistry; Elsevier: Amsterdam, The Netherlands, 2018; pp. 161-169. [CrossRef]

76. Huang, K.S.; Yang, C.H.; Huang, S.L.; Chen, C.Y.; Lu, Y.Y.; Lin, Y.S. Recent Advances in Antimicrobial Polymers: A Mini-Review. Int. J. Mol. Sci. 2016, 17, 1578. [CrossRef]

77. Ortega, A.; Farah, S.; Tranque, P.; Ocaña, A.V.; Nam-Cha, S.H.; Beyth, N.; Gómez-Roldán, C.; Pérez-Tanoira, R.; Domb, A.J.; Pérez-Martínez, F.C.; et al. Antimicrobial Evaluation of Quaternary Ammonium Polyethyleneimine Nanoparticles against Clinical Isolates of Pathogenic Bacteria. IET Nanobiotechnol. 2015, 9, 342-348. [CrossRef] [PubMed]

78. Priyadarsini, S.; Mukherjee, S.; Mishra, M. Nanoparticles Used in Dentistry: A Review. J. Oral. Biol. Craniofac. Res. 2018, 8, 58-67. [CrossRef]

79. AlKahtani, R.N. The Implications and Applications of Nanotechnology in Dentistry: A Review. Saudi Dent. J. 2018, 30, 107-116. [CrossRef]

80. Beyth, N.; Yudovin-Farber, I.; Bahir, R.; Domb, A.J.; Weiss, E.I. Antibacterial Activity of Dental Composites Containing Quaternary Ammonium Polyethylenimine Nanoparticles against Streptococcus Mutans. Biomaterials 2006, 27, 3995-4002. [CrossRef] [PubMed]

81. Beyth, N.; Yudovin-Farber, I.; Basu, A.; Weiss, E.I.; Domb, A.J. Antimicrobial Nanoparticles in Restorative Composites. In Emerging Nanotechnologies in Dentistry, 2nd ed.; Subramani, K., Ahmed, W., Eds.; Elsevier: Amsterdam, The Netherlands, 2018. [CrossRef]

82. Domb, A.J.; Weiss, E.; Beyth, N.; Farber, I.; Perez-Davidi, M. Antimicrobial Nanoparticulate Additives Forming Non-Leachable Sustained Antimicrobial Polymeric Compositions. U.S. Patent 20080226728A1, 18 September 2008.

83. Farah, S.; Khan, W.; Ira, Y.F.; Kesler Shvero, D.; Beyth, N.; Weiss, E.; Domb, A. Crosslinked QA-PEI Nanoparticles: Synthesis Reproducibility, Chemical Modifications, and Stability Study. Polym. Advan. Technol. 2013, 24, 446-452. [CrossRef]

84. Nuzhdina, A.V.; Morozov, A.S.; Kopitsyna, M.N.; Strukova, E.N.; Shlykova, D.S.; Bessonov, I.V.; Lobakova, E.S. Simple and Versatile Method for Creation of Non-Leaching Antimicrobial Surfaces Based on Cross-Linked Alkylated Polyethyleneimine Derivatives. Mater. Sci. Eng. C Mater. Biol. Appl. 2017, 70, 788-795. [CrossRef]

85. Yudovin-Farber, I.; Beyth, N.; Weiss, E.I.; Domb, A.J. Antibacterial Effect of Composite Resins Containing Quaternary Ammonium Polyethyleneimine Nanoparticles. J. Nanopart. Res. 2010, 12, 591-603. [CrossRef]

86. Yew, P.Y.M.; Chee, P.L.; Cally, O.; Zhang, K.; Liow, S.S.; Lohn, X.J. Quarternized Short Polyethylenimine Shows Good Activity against Drug-Resistant Bacteria. Macromol. Mater. Eng. 2017, 302, 1700186. [CrossRef]

87. Azzam, T.; Eliyahu, H.; Shapira, L.; Linial, M.; Barenholz, Y.; Domb, A.J. Polysaccharide-oligoamine based conjugates for gene delivery. J. Med. Chem. 2002, 45, 1817-1824. [CrossRef]

88. Zaltsman, N.; Kesler-Shvero, D.; Weiss, E.I.; Beyth, N. Synthesis Variants of Quaternary Ammonium Polyethyleneimine Nanoparticles and Their Antibacterial Efficacy in Dental Materials. J. Appl. Biomater. Funct. Mater. 2016, 14, e205-e211. [CrossRef]

89. Youdovin-Farber, I.; Beyth, N.; Nyska, A.; Weiss, E.I.; Golenser, J.; Domb, A.J. Surface Characterization and Biocompatibility of Restorative Resin Containing Nanoparticles. Biomacromolecules 2008, 9, 3044-3050. [CrossRef] [PubMed] 
90. Beyth, N.; Houri-Haddad, Y.; Baraness-Hadar, L.; Yudovin-Farber, I.; Domb, A.J.; Weiss, E.I. Surface Antimicrobial Activity and Biocompatibility of Incorporated Polyethylenimine Nanoparticles. Biomaterials 2008, 29, 4157-4163. [CrossRef] [PubMed]

91. Beyth, N.; Yudovin-Farber, I.; Perez-Davidi, M.; Domb, A.J.; Weiss, E.I. Polyethyleneimine nanoparticles incorporated into resin composite cause cell death and trigger biofilm stress in vivo. Proc. Natl. Acad. Sci. USA 2010, 107, 22038-22043. [CrossRef] [PubMed]

92. Pietrokovski, Y.; Nisimov, I.; Kesler-Shvero, D.; Zaltsman, N.; Beyth, N. Antibacterial Effect of Composite Resin Foundation Material Incorporating Quaternary Ammonium Polyethyleneimine Nanoparticles. J. Prosthet. Dent. 2016, 116, 603-609. [CrossRef]

93. Shvero, D.K.; Zatlsman, N.; Hazan, R.; Weiss, E.I.; Beyth, N. Characterization of the Antibacterial Effect of Polyethyleneimine Nanoparticles in Relation to Particle Distribution in Resin Composite. J. Dent. 2015, 43, 287-294. [CrossRef] [PubMed]

94. Zaltsman, N.; Kesler Shvero, D.; Polak, D.; Weiss, E.I.; Beyth, N. Antibacterial Orthodontic Adhesive Incorporating Polyethyleneimine Nanoparticles. Oral Health Prev. Dent. 2017, 15, 245-250. [CrossRef]

95. Varon-Shahar, E.; Sharon, E.; Zabrovsky, A.; Houri-Haddad, Y.; Beyth, N. Antibacterial Orthodontic Cements and Adhesives: A Possible Solution to Streptococcus Mutans Outgrowth Adjacent to Orthodontic Appliances. Oral. Health Prev. Dent. 2019, 17, 49-56. [CrossRef]

96. Beyth, S.; Polak, D.; Milgrom, C.; Weiss, E.I.; Matanis, S.; Beyth, N. Antibacterial Activity of Bone Cement Containing Quaternary Ammonium Polyethyleneimine Nanoparticles. J. Antimicrob. Chemother. 2014, 69, 854-855. [CrossRef]

97. Shvero, D.K.; Davidi, M.P.; Weiss, E.I.; Srerer, N.; Beyth, N. Antibacterial Effect of Polyethyleneimine Nanoparticles Incorporated in Provisional Cements against Streptococcus Mutans. J. Biomed. Mater. Res. Part B Appl. Biomater. 2010, 94, 367-371. [CrossRef]

98. Abramovitz, I.; Beyth, N.; Weinberg, G.; Borenstein, A.; Polak, D.; Kesler-Shvero, D.; Houri-Haddad, Y. In Vitro Biocompatibility of Endodontic Sealers Incorporating Antibacterial Nanoparticles. J. Nanomater. 2012, 858073. [CrossRef]

99. Lambert, P.A. Mechanisms of Antibiotic Resistance in Pseudomonas Aeruginosa. J. R. Soc. Med. 2002, 95, 22-26.

100. Farah, S.; Aviv, O.; Laout, N.; Ratner, S.; Beyth, N.; Domb, A.J. Quaternary Ammonium Polyethylenimine Nanoparticles for Treating Bacterial Contaminated Water. Colloids. Surf. B 2015, 128, 614-619. [CrossRef] [PubMed]

101. Franklin, T.J.; Snow, G.A. Attack and Defense: Drug Transport across Cell Walls and Membranes. In Biochemistry and Molecular Biology of Antimicrobial Drug Action; Springer: Boston, MA, USA, 2005; pp. 121-134.

102. Barszczewska-Rybarek, I.M. A Guide through the Dental Dimethacrylate Polymer Network Structural Characterization and Interpretation of Physico-Mechanical Properties. Materials 2019, 12, 4057. [CrossRef]

103. Morrison, R.T.; Boyd, R.N. Chemia Organiczna, 2nd ed.; PWN: Warsaw, Poland, 1990; pp. 533-534.

104. Hamlin, T.A.; Swart, M.; Bickelhaupt, F.M. Nucleophilic Substitution (SN2): Dependence on Nucleophile, Leaving Group, Central Atom, Substituents, and Solvent. ChemPhysChem 2018, 19, 1315-1330. [CrossRef]

105. Xue, Y.; Xiao, H.; Zhang, Y. Antimicrobial polymeric materials with quaternary ammonium and phosphonium salts. Int. J. Mol. Sci. 2015, 16, 3626-3655. [CrossRef]

106. Baliga, S.; Muglikar, S.; Kale, R. Salivary pH: A diagnostic biomarker. J. Indian Soc. Periodontol. 2013, 17, 461-465. [CrossRef]

107. Venkatesh, M.; Barathi, V.A.; Goh, E.T.L.; Anggara, R.; Fazil, M.H.U.T.; Ng, A.J.Y.; Harini, S.; Aung, T.T.; Fox, S.J.; Liu, S.; et al. Antimicrobial activity and cell selectivity of synthetic and biosynthetic cationic polymers. Antimicrob. Agents Chemother. 2017, 61, e0469-17. [CrossRef] [PubMed]

108. Jiao, Y.; Niu, L.; Ma, S.; Li, J.; Tay, F.R.; Chen, J. Quaternary ammonium-based biomedical materials: State-of-the-art, toxicological aspects and antimicrobial resistance. Prog. Polym. Sci. 2017, 71, 53-90. [CrossRef]

109. Forssten, S.D.; Björklund, M.; Ouwehand, A.C. Streptococcus Mutans, Caries and Simulation Models. Nutrients 2010, 2, 290-298. [CrossRef]

110. Loesche, W.J. Role of Streptococcus Mutans in Human Dental Decay. Microbiol. Rev. 1986, 50, 353-380. [CrossRef] [PubMed] 
111. Matsumoto-Nakano, M. Role of Streptococcus mutans surface proteins for biofilm formation. Jpn. Dent. Sci. Rev. 2018, 54, 22-29. [CrossRef]

112. 3M FiltekTM Z250 Universal Restorative System, Technical Product Profile. Available online: https://multimedia.3m.com/mws/media/78343O/3m-filtek-z250-universal-restorative-technicalproduct-profile.pdf (accessed on 29 August 2020).

113. 3MTM Single Bond Universal Adhesive, Technical Product Profile. Available online: https://multimedia.3m. $\mathrm{com} / \mathrm{mws} / \mathrm{media} / 1279637 \mathrm{O} / 3 \mathrm{~m}$-single-bond-universal-adhesive-technical-product-profile.pdf (accessed on 29 August 2020).

114. FiltekTM Supreme XT Flowable Restorative, Technical Product Profile. Available online: https://multimedia. 3m.com/mws/media/598213O/filtek-supreme-xt-flow-tpp.pdf (accessed on 29 August 2020).

115. FiltekTM Supreme XTE Flowable Restorative, Technical Product Profile. Available online: https://multimedia.3m.com/mws/media/715606O/filtek-supreme-xte-flowable-technical-profile-anz. pdf?fn=supr_xte_fl_tpp.pdf (accessed on 29 August 2020).

116. Jefferies, R.S. Abrasive Finishing and Polishing in Restorative Dentistry: A State-of-the-Art Review. Dent. Clin. N. Am. 2007, 51, 379-397. [CrossRef] [PubMed]

117. Zhang, N.; Melo, M.A.S.; Chen, C.; Liu, J.; Weir, M.D.; Bai, Y.; Xu, H.K.H. Development of a multifunctional adhesive system for prevention of root caries and secondary caries. Dent. Mater. 2015, 31, 1119-1131. [CrossRef]

118. Perdigāo, J. Current perspectives on dental adhesion: (1) Dentin Adhesion-Not there yet. Jpn. Dent. Sci. Rev. 2020. [CrossRef]

119. Dressano, D.; Salvadro, M.V.; Oliveira, M.T.; Marchi, G.M.; Fronza, B.M.; Hadis, M.; Palin, W.M.; Lima, A.F. Chemistry of novel and contemporary resin-based dental adhesives. J. Mech. Behav. Biomed. Mater. 2020, 110, 103875. [CrossRef]

120. Sharon, E.; Shrabi, R.; Eden, A.; Zabrovsky, A.; Ben-Gal, G.; Sharon, E.; Pietrokovski, Y.; Houri-Haddad, Y.; Beyth, N. Antibacterial Activity of Orthodontic Cement Containing Quaternary Ammonium Polyethylenimine Nanoparticles Adjacent to Orthodontic Brackets. Int. J. Environ. Res. Public Health 2018, 15, 606. [CrossRef]

121. Frazer, R.Q.; Byron, R.T.; Osborne, P.B.; West, K.P. PMMA: An Essential Material in Medicine and Dentistry. J. Long. Term. Eff. Med. Implants 2005, 15, 629-639. [CrossRef]

122. Fonseca, D.A.; Paula, A.B.; Marto, C.M.; Coelho, A.; Paulo, S.; Martinho, J.P.; Carrilho, E.; Ferreira, M.M. Biocompatibility of Root Canal Sealers: A Systematic Review of In Vitro and In Vivo Studies. Materials 2019, 12, 4113. [CrossRef]

Publisher's Note: MDPI stays neutral with regard to jurisdictional claims in published maps and institutional affiliations.

(C) 2020 by the authors. Licensee MDPI, Basel, Switzerland. This article is an open access article distributed under the terms and conditions of the Creative Commons Attribution (CC BY) license (http://creativecommons.org/licenses/by/4.0/). 